\title{
Mechanistic investigations towards a successful PET with Breslow-Intermediates
}

Jenny Phan, Julia Rehbein*

Fakultät für Chemie \& Pharmazie, Universität Regensburg, Universitätsstrasse 31, 93051 Regenburg

Even under standard catalysis reaction conditions Breslow-intermediates can undergo oxidations that feature NHC stabilized radicals as usually transient intermediates. The idea of making this oxidation step the main reaction pathway and hence harness the ketyl type radicals had previously been proposed by Rehbein et al. Here recent mechanistic studies are summarized to identify the prerequisites to achieve a successful and universally applicable dual NHC-photoredox catalysis that enables the reagent-independent formation of ketyl radicals that may be subsequently trapped by suitable substrates to form new carbon-carbon or carbon heteroatom bonds.

Introduction. NHC-catalysis is a long established form of asymmetric organocatalysis ${ }^{1}$ that allows for the umpolung of the inherent electrophilic character of carbonyls. ${ }^{2}$ Rather late in regard to the methodological development and mechanistic postulates and associated studies ${ }^{3,4}$ the idea evolved that single electron transfer (SET) or proton-coupled electron transfer (PCET) may play a role in the pathways involving the key enaminol structure EA (Scheme 1). ${ }^{5,6,7}$ Detailed studies regarding the origin of EPR-observable open-shell structures $(\mathrm{R})$ and their potential role within the NHC-catalytic cycle let to the conclusion that most likely the Breslow intermediate is the direct precursor of such NHCstabilized ketyl type radicals (OH-EA-R, EA-dep-R). Structures like EA-dep-R have been proposed in the oxidative NHC-catalysis, but only as an intermediate to the full-two-electron oxidation to feature acyl azolium species. ${ }^{8}$ Our interest evolves around the differentiation of the reactivities of the various possible radical structures and their selective formation, i.e. to derive a universal reactivity map under given reaction conditions. As depicted in Scheme 1, one can classify these radicals $\mathbf{R}$ according to their charge (neutral: EA-dep-R, OH-PA-R; cationic: OH-EA-R, anionic: PA-dep-R) and their ability to accept or donate a hydrogen atom. Hence, quite different chemoselectivity and pathways are expected.

\footnotetext{
${ }^{1}$ R. Kluger, K. Tittmann, Chem. Rev. 2008, 108, 1797-1833.

${ }^{2}$ R. Breslow, J. Am. Chem. Soc. 1958, 80, 3719-3726.

${ }^{3}$ M. J. White, F. J. Leeper, J. Org. Chem. 2001, 66, 5124-5131.

${ }^{4}$ (a) M. Paul, M. Breugst, J.-M. Neudörfl, R. B. Sunoj, A. Berkessel, J. Am. Chem. Soc. 2016, 138, 5044-5051. (b) A. Berkessel, V. R. Yatham, S. Elfert, J. -M. Neudörfl, Angew. Chem. Int. Ed. 2013, 52, 11158-11162. (c) A. Berkessel, S. Elfert, V. R. Yatham, J. -M. Neudörfl, N. E. Schlörer 2012, 51, 12370-12374. (d) A. Berkessel, S. Elfert, K. Etzenbach-Effers, J. H. Teles, Angew. Chem. Int. Ed. 2010, 49, 7120-7124.

${ }^{5}$ (a) J. Phan, S.-M. Ruser, K. Zeitler, J. Rehbein EJOC 2018, 2-3, 557-561. (b) J. Rehbein, S.-M. Ruser, J. Phan Chem. Sci. 2015, 6, 6013-6018.

${ }^{6}$ Vianney Regnier. Erik A. Romero, Florian Molton, Rodolphe Jazzar, Guy Bertrand, David Martin J. Am. Chem. Soc. 2019, 141, 2, 1109-1117.

${ }^{7}$ M.-H. Hsieh, G.-T. Huang, J.-S. K. Yu, J. Org. Chem. 2018, 83, 15202-15209.

8 J. Guin, S. De Sarkar, S. Grimme, A. Studer Angew. Chem. Int. Ed. 2008, 47, 8727-8730.
} 


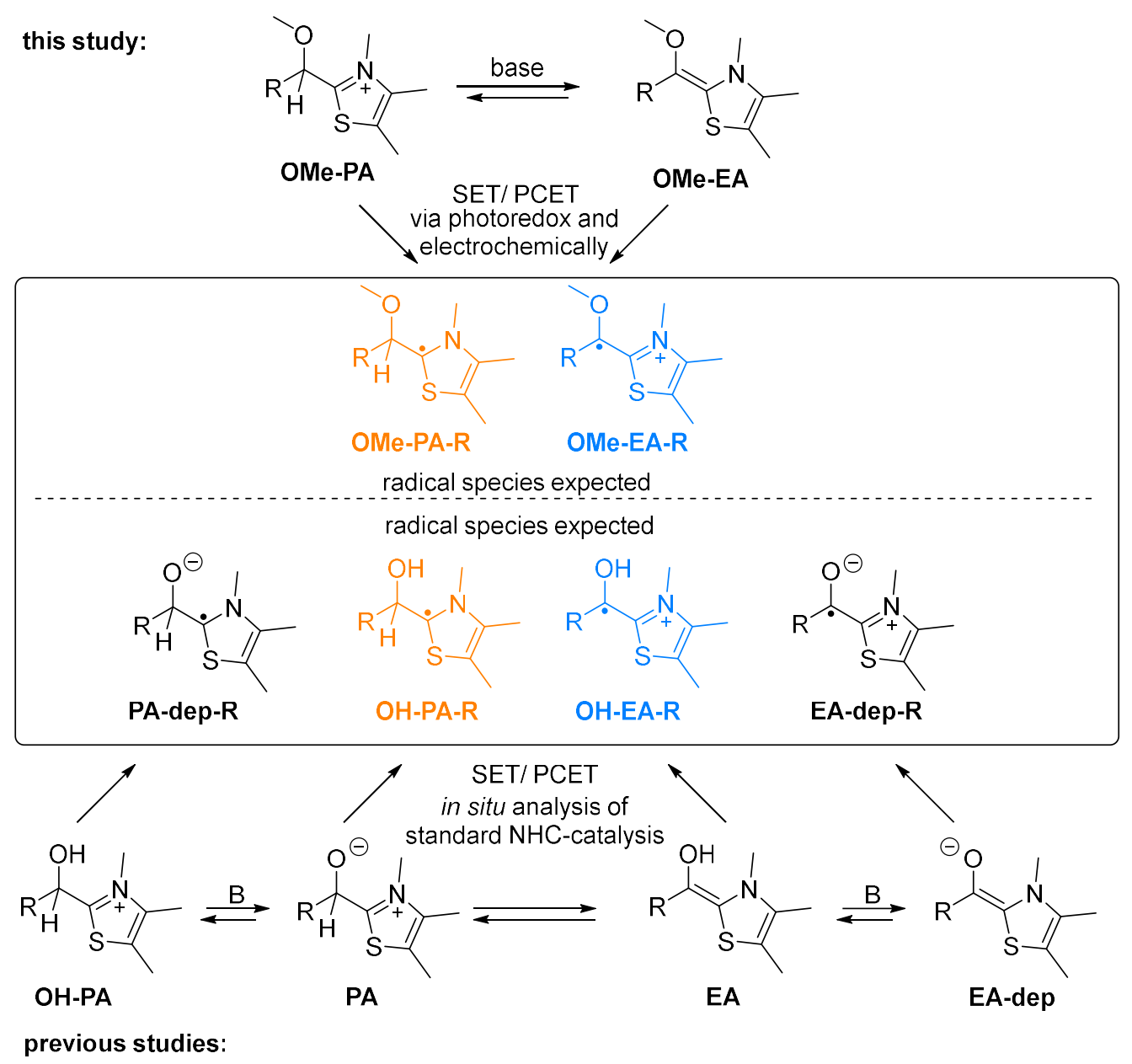

Scheme 1. The key structure of standard NHC-catalysis cycles (bottom part) in the activation of simple aldehyde. The radicals EA-dep-R and OH-EA-R were previously characterized and analyzed regarding their reactivity and their most likely pathway of formation. Highlighted are the similarities between the here studied O-methylated radical species OMe-PA-R and OMeEA-R formed via photoredox catalysis and electrochemistry.

Since standard Breslow intermediates (EA) and primary adducts (PA) are rather fleeting in nature, we decided to make use of the stable $O$-methylated derivates for our mechanistic studies. This approach has the advantages that we have defined starting points for the interaction with the photocatalysts and for electrochemical conversions, it reduces the number of possible acid-base and other preequilibria and can test for the broad range of substrate electronics. The following results hence mimic the situation where the Breslow-intermediate is in its neutral state (EA) and the primary adduct in its cationic form. These two structures are the ones that are most likely to occur under the widely used protic conditions in standard NHC-catalysis and have also been identified by NMR spectroscopy. ${ }^{3,4}$ The synthesis of OMe-PA and OMe-EA for $\mathrm{R}=\mathrm{Ph}$ was accomplished as previously described ${ }^{9,10,11}$.

These general questions are addressed in the following: Which conditions are needed to have an efficient photoelectron transfer from the excited state photocatalyst (PC*)? Will the photoredox step involving the PC* take place with the enaminol OMe-EA selectively or are site-reactions expected with the primary adduct OMe-PA? In this regard, how are the OMe-EA and the OMe-PA linked via redox-

\footnotetext{
${ }^{9}$ V. Capriati, S. Florio, G. Ingrosso, C. Granito, L. Troisi, Eur. J. Org. Chem. 2002, 478-484.

${ }^{10}$ G. Barletta, A. C. Chung, C. B. Rios, F. Jordan, J. M. Schlegel, J. Am. Chem. Soc. 1990, 112, 8144-8149.

${ }^{11}$ B. Maji, H. Mayr, Angew. Chem. Int. Ed. 2012, 51, 10408-10412.
} 
steps (SET vs. PCET). The answers were seeked by a combination of photophysical experiments, like quenching studies and spectro-electro chemistry.

Results \& Discussions. Based on previously published CV-data the choice of photoredox catlaysts was made. ${ }^{5}\left[\mathrm{Ru}(\mathrm{bpy})_{3}\right]^{2+}$ and Eosin $\mathrm{Y}$ both have enough redox-potential to access the according SET-derived radicals from primary adduct OMe-PA and Breslow-intermediate OMe-EA. To avoid complications due to the $\mathrm{pH}$-dependence of the structure of Eosin $\mathrm{Y}$, the disodium salt was used $\left(\mathrm{Na}_{2} \operatorname{Eosin} \mathrm{Y}\right)$.

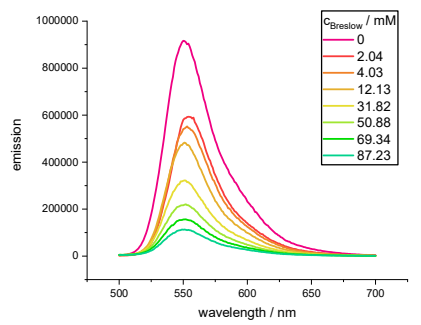

A

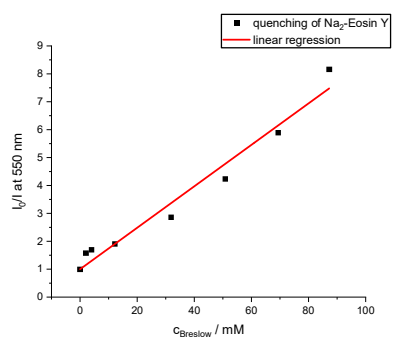

B

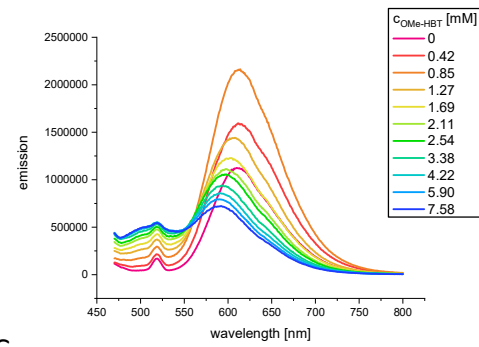

C

Figure 1. Stern-Vollmer plot $\left(B ; I_{0}\right.$ maximal intensity at COMe-EA $=0 ; I$ at $C_{i}$, OMe-EA; linear regression with $\left.R^{2}=0.99\right)$ derived of the fluorescence $(550 \mathrm{~nm})$ quenching of the $\mathrm{Na}_{2}$ Eosin $\mathrm{Y}$ with OMe-EA (A). Excitation of $\mathrm{Na}_{2} \mathrm{Eosin} \mathrm{Y}$ with $480 \mathrm{~nm}$, emission in the $500-700 \mathrm{~nm}$ range, slit width $1 \mathrm{~nm}$. C) Same quenching experiment with $\left[\mathrm{Ru}(\mathrm{bpy})_{3}\right] \mathrm{Cl}_{2}$.

The quenching of the two (Table 1, Figure 1) photoredox-catalysts with OMe-PA and OMe-EA with and without sacrificial oxidant or reductant showed that only the Breslow-intermediate OMe-EA was able to quench the PC*. This finding was supported by the EPR-spectra taken during irradiation (Figure 2, additional information see $\mathrm{SI}$ ). In case of OMe-PA no radical signal was observed. These results suggest that also under standard catalysis conditions (in protic polar media) with transients OH-PA and EA being present the selectivity of the redox-steps is highly in favor to take place only with the EA. In regard to the choice of photocatalyst the quenching constants suggest that the $\mathrm{Na}_{2} \operatorname{Eosin} \mathrm{Y}$ is a good lead-structure, with a quenching rate constant being $5.7 \times 10^{4}$ times higher than with $\left[\mathrm{Ru}(\mathrm{bpy})_{3}\right] \mathrm{Cl}_{2}$ (Table 1).

Table 1. Overview of the quenching experiments with OMe-EA using two different PCs and reductive (DIPEA) and oxidative additives ( $m$-dinitrobenzene, $m$-DNB).

\begin{tabular}{|c|c|c|c|c|c|c|c|c|}
\hline \multirow[b]{2}{*}{ \# } & \multicolumn{4}{|c|}{$\left[\mathrm{Ru}(\mathrm{bpy})_{3}\right] \mathrm{Cl}_{2}$} & \multicolumn{4}{|c|}{$\mathrm{Na}_{2} \operatorname{Eosin} \mathrm{Y}$} \\
\hline & additive & $\begin{array}{c}\mathrm{K}_{\mathrm{sv}} \\
{\left[\mathrm{L} \cdot \mathrm{mol}^{-1}\right]}\end{array}$ & $\begin{array}{c}\mathrm{k}_{\mathrm{q}} / \\
\mathrm{L} \cdot(\mathrm{mol} \cdot \mathrm{s})^{-1}\end{array}$ & $\begin{array}{c}\text { EPR } \\
\text { active }\end{array}$ & additive & $\begin{array}{c}\mathrm{K}_{\mathrm{sv}} \\
{\left[\mathrm{L} \cdot \mathrm{mol}^{-1}\right]}\end{array}$ & $\begin{array}{c}\mathrm{k}_{\mathrm{q}} / \\
\mathrm{L} \cdot(\mathrm{mol} \cdot \mathrm{s})^{-1}\end{array}$ & $\begin{array}{c}\text { EPR } \\
\text { active }\end{array}$ \\
\hline 1 & DIPEA & 1.08 & $3.09 \cdot 10^{6}$ & $X$ & DIPEA & 0.699 & $5.78 \cdot 10^{8}$ & $X$ \\
\hline 2 & none & 1.08 & $4.51 \cdot 10^{8}$ & $x$ & none & 74.3 & $6.14 \cdot 10^{10}$ & $x$ \\
\hline 3 & $m$-DNB & 55.3 & $1.58 \cdot 10^{8}$ & $x$ & $m$-DNB & 78.5 & $6.49 \cdot 10^{10}$ & $x$ \\
\hline
\end{tabular}

The in situ EPR-spectra taken under irradiation of the reaction solution at $530 \mathrm{~nm}\left(\mathrm{Na}_{2}\right.$ Eosin $\left.\mathrm{Y}\right) / 455$ $\mathrm{nm}\left(\left[\mathrm{Ru}(\mathrm{bpy})_{3}\right] \mathrm{Cl}_{2}\right)$ were used to decide on the possible requirement of sacrificial electron donors or acceptors. As a read-out for the efficiency of the SET process the intensity (double integration of the observed signal) of the EPR-spectra were used to determine when the formation of the ketyl-type radical species is highest (Table 2 ). In line with the highest quenching rate of the Breslow intermediate OMe-EA without any additive and $\mathrm{Na}_{2}$ Eosin $\mathrm{Y}$ yielded the highest spin concentrations. 
Table 2. Observed changes in the EPR-intensities with the two different PCs and different additive.

\begin{tabular}{|c|c|c|c|c|}
\hline \# & PC & additive & $\begin{array}{c}\text { EPR } \\
\text { intensity }{ }^{a, b}\end{array}$ & $\begin{array}{c}\text { relative EPR } \\
\text { intensity }\end{array}$ \\
\hline 1 & $\mathrm{Na}_{2}$ Eosin $\mathrm{Y}$ & none & 792 & 7.0 \\
\hline 2 & $\mathrm{Na}_{2}$ Eosin $\mathrm{Y}$ & Pyridine & 521 & 4.6 \\
\hline 3 & $\mathrm{Na}_{2}$ Eosin $\mathrm{Y}$ & DIPEA & 218 & 1.9 \\
\hline 4 & $\mathrm{Na}_{2}$ Eosin $\mathrm{Y}$ & TEA & 175 & 1.5 \\
\hline 5 & $\mathrm{Na}_{2}$ Eosin $\mathrm{Y}$ & $\mathrm{K}_{2} \mathrm{~S}_{2} \mathrm{O}_{8}$ & 343 & 3.0 \\
\hline 6 & {$\left[\mathrm{Ru}(\mathrm{bpy})_{3}\right] \mathrm{Cl}_{2}$} & Pyridine & 430 & 3.8 \\
\hline 7 & {$\left[\mathrm{Ru}(\mathrm{bpy})_{3}\right] \mathrm{Cl}_{2}$} & $\mathrm{~K}_{2} \mathrm{~S}_{2} \mathrm{O}_{8}$ & 113 & 1.0 (ref.) \\
\hline
\end{tabular}

${ }^{a}$ after 10 min of irradiation. ${ }^{b}$ based on integrated area (double integration of observed signal)

In presence of additives not only the quenching rates of PC* are partially lowered (amines) but also the radical concentrations in comparison to the reaction solutions without any additives. The latter observation can either be explained by three different scenarios: First, the competition between additive and OMe-PA in the quenching of the PC*. Second, by an onwards reaction of the formed OMePA-R with the additive to a closed shell species. Third, by an effective pre-complexation of PC or OMeEA prior to irradiation which is suspended or triggered by the presence of an additive.

Table 3. Comparison of the quenching rates $\mathrm{k}_{\mathrm{q}}$ of the additives and OMe-PA in degassed THF.

\begin{tabular}{|c|c|c|c|c|c|c|c|c|}
\hline \# & PC & $\begin{array}{c}\mathrm{c} \text { in THF } \\
{[\mu \mathrm{M}]}\end{array}$ & quencher & $\begin{array}{l}\mathrm{c} \text { in } \\
\text { THF } \\
{[\mathrm{M}]}\end{array}$ & $\begin{array}{c}\mathrm{K}_{\mathrm{sv}} \\
{[\mathrm{L} / \mathrm{mol}]} \\
\times 10^{-4}\end{array}$ & $\begin{array}{c}\mathrm{k}_{\mathrm{F}}+\mathrm{k}_{\mathrm{nr}}=1 / \tau \\
{[1 / \mathrm{s}]}\end{array}$ & $\begin{array}{c}\mathbf{k}_{\mathrm{q}} \\
{[\mathrm{L} / \mathrm{mol} / \mathrm{s}]} \\
\times 10^{8}\end{array}$ & $k_{q, \text { rel }}$ \\
\hline 1 & & 10 & DIPEA & neat & 8 & 826446281 & 6.68 & 1 \\
\hline 2 & $\mathrm{Na}_{2}$ Eosin- $\mathrm{Y}$ & 10 & $\mathrm{mDNB}$ & 1.2 & 600 & 826446281 & 496 & 74 \\
\hline 3 & & 9 & OMe-EA & 1.2 & 773 & 826446281 & 639 & 96 \\
\hline 7 & & 8 & DIPEA & neat & 11 & 2857142 & 0.03 & 1 \\
\hline 8 & $\mathrm{Ru}($ bipy $){ }_{3} \mathrm{Cl}_{2}$ & 11 & $\mathrm{mDNB}$ & 1.2 & 695 & 2857142 & 20 & 667 \\
\hline 9 & & 8 & OMe-EA & 1.3 & 700 & 2857142 & 20 & 667 \\
\hline
\end{tabular}

Based on the independent quenching rates measured for the two PCs by the different additives in comparison to OMe-EA (Table 3) the first hypothesis may be applicable for the oxidizing, but not for the reducing additives. In case of the reducable additives $\left(m-D N B, \mathrm{~K}_{2} \mathrm{~S}_{2} \mathrm{O}_{8}\right)$ the quenching rates are very similar to the ones of OMe-EA and hence the observation of unchanged quenching constants but lower amounts of OMe-EA-R may be explained by a competition for PC* (Table 3, Entries 2, 3, 8, 9). In case of the amines the situation is somewhat different. OMe-EA is $96\left(\mathrm{Na}_{2} \mathrm{Eosin}_{\mathrm{Y}}\right)$ to $667\left(\left[\mathrm{Ru}(\mathrm{bpy})_{3}\right] \mathrm{Cl}_{2}\right)$ times faster than the amine in quenching the PC*. Still the quenching rate of PC* in the reaction solution is diminished for both PCs as well as the concentration of OMe-EA-R (Table 2).

The above mentioned hypothesis of assembly formations of the three components in different permutations like PC•OMe-EA, PC•PC or OMe-EA•amine was pursued first. Although Brønsted acidbase interactions with OMe-PA and the amine prior to irradiation seem unlikely, UV-vis spectra of OMe-EA recorded as a function of CDIPEA and by the quenching studies of the OMe-EA fluorescence (Figure 2). As both, UV-vis absorption and fluorescence are continuously enhanced with rising base concentrations an assembly formation already in the electronic ground state between these two 
molecular species is likely. This type of assembly is deemed to be undesired as it apparently leads to a less efficient quenching of PC*.

That a similar assembly between PC and OMe-EA prior to the SET step especially between $\left[\mathrm{Ru}(\mathrm{bpy})_{3}\right] \mathrm{Cl}_{2}$ and OMe-EA is a likely option can be derived from the quenching experiments shown above (Figure 1B). The shift of the wavelength and initial increase of the fluorescence upon continuous addition of OMe-EA indicate a molecular association step of both structures. Such an assembly might allow for a very efficient PET. Therefore, the efficiency of this interaction between PC and OMe-EA was studied further by determining the possibility of a dark redox-reaction between PC and OMe-EA, that would require and hence prove the pre-association of both structures independently of the Stern-Volmer quenching studies (Figure 3B-D).
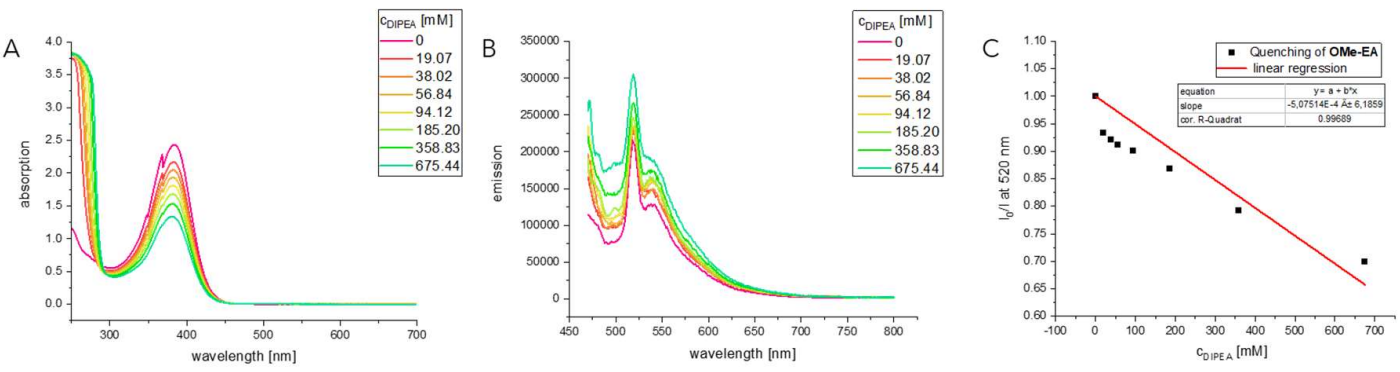

Figure 2. A: UV-vis absorption spectra of OMe-EA during the titration with DIPEA. The absorption maximum increases continuously with the base concentration indicating the complex formation in the electronic ground state. B: Fluorescence quenching of OMe-EA with DIPEA; irradiation at $450 \mathrm{~nm}$ (slitwidth: $6 \mathrm{~nm}$ ), emission: $470-800 \mathrm{~nm}$ (slid width: $6 \mathrm{~nm}$ ) C: associated Stern-Volmer plot to B.

In case of both PCs the radical concentration in presence of OMe-EA and pyridine or $\mathrm{K}_{2} \mathrm{~S}_{2} \mathrm{O}_{8}$ is significantly above zero even without light (Figure 3B-D). In case of the oxidative additives the oxidation of the OMe-EA may take place and was also shown by the EPR-spectra of the control experiments. In case of the amines this rational is not applicable. However, further control experiments by EPR spectroscopy could show that it is not the PC itself or its interaction with pyridine (see SI) or an interaction between pyridine and OMe-EA that gave rise to the observed dark reaction. This leaves a thermally activated SET process within an assembly of OMe-EA and PC as the only rational.

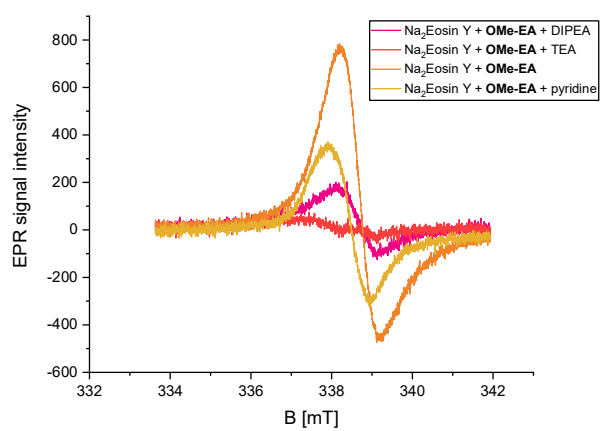

A

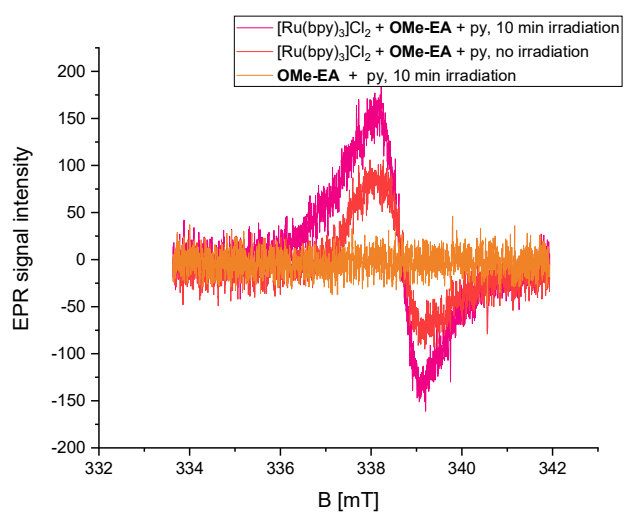




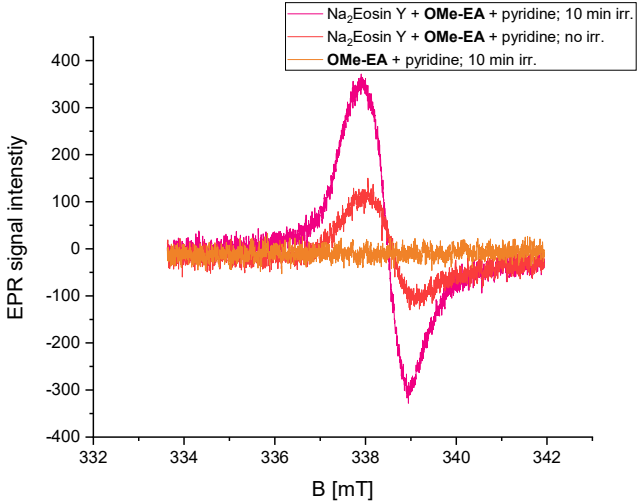

C

Figure 3. EPR monitoring of the reaction solutions (OMe-PA, PC (5 mol\%), 2 eq or no additive in degassed THF) during irradiation at $\mathrm{t}=10 \mathrm{~min}$ : A) with $\mathrm{Na}_{2} \operatorname{Eosin} \mathrm{Y}\left(\lambda_{\text {irr }}=530 \mathrm{~nm}\right)$ and different amine bases (2 eq);B) comparison with $\left[\mathrm{Ru}(\mathrm{bpy})_{3}\right]_{2} \mathrm{Cl}{ }_{2}$ and 2 eq pyridine $\left(\lambda_{\text {irr }}=455 \mathrm{~nm}\right) \mathrm{C}$ ) $\mathrm{Na}_{2}$ Eosin $\mathrm{Y}$ in presence of pyridine (2 eq) without irradiation. D) Comparison of dark background reaction in dependence of PC and OMe-EA-R. measurement conditions: mean field $337.784 \mathrm{mT}$, width: $8.305 \mathrm{mT}$, $\mu$ wave power: $10 \mathrm{~mW}, t: 30 \mathrm{~s}$, amplitude of modulation: $0.7 \mathrm{mT}$, reciever gain: $10 \mathrm{~dB}$.

With this assembly in place the hypothesis of the amine acting as a reactant for OMe-EA-R is not ruled out yet. Therefore, the concentration of OMe-EA-R was measured by EPR in dependence on the amine structure. Since reactions with TEA and also DIPEA led to a stronger loss in radical concentration than pyridine (Figure 2A) a HAT pathway from amine to OMe-EA-R seems most likely. Consequences for an attempted dual catalysis approach would be to avoid amine bases that feature HAT reactivity, since these can apparently transform the OMe-EA-R derived from the PET process of the OMe-EA back into the photoredox inactive primary adduct OMe-PA. The direct HAT-relationship between the protected Breslow- and primary adduct was shown in an independent set of spectro-electrochemical experiments (Figure 3, discussion vide infra).
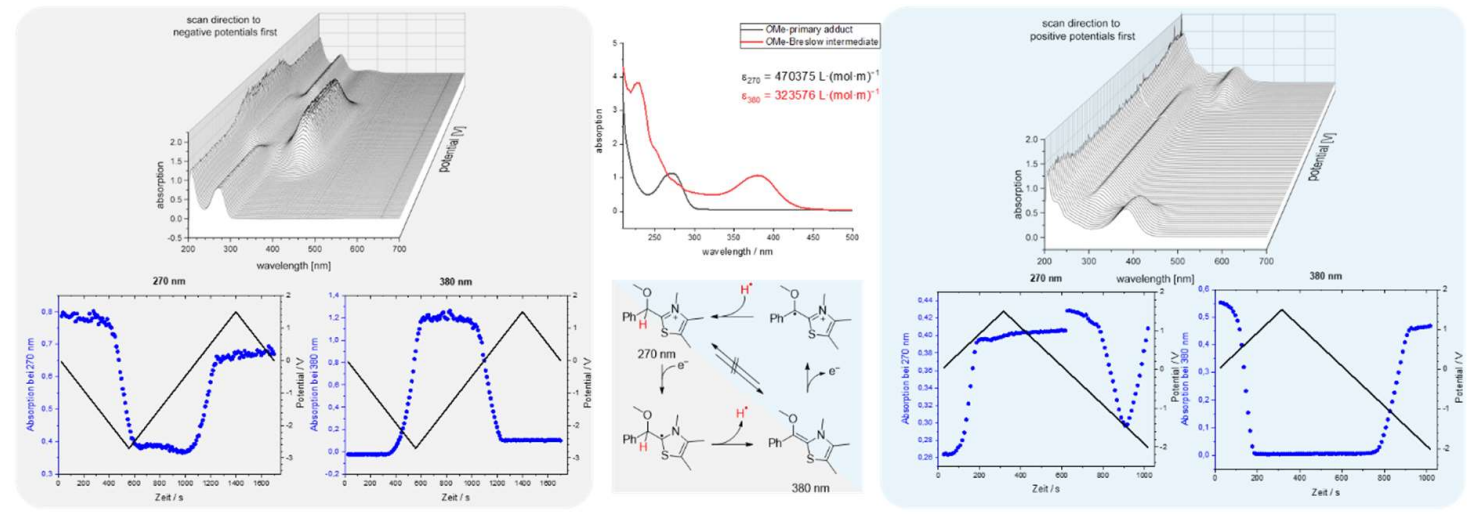

Figure 3. Summary of the spectro-electrochemical studies of OMe-PA (left) and OMe-EA (right) in THF using the UV-vis absorption as a read out to identify the resulting intermediates. Clearly there is a PCET interconnection under these electrochemical conditions between OMe-PA and OMe-EA that most likely is mimicked under photoredox-catalytic conditions in presence of HAT-donors/acceptors.

To elucidate further if the hypothesis of a direct transformation of OMe-EA to OMe-PA and vice versa via a PCET is possible spectro-electrochemical experiments were conducted. Hereby, the UV-vis spectra were record whilst driving the potential of the electrochemical cell until oxidation or reduction peak potentials of OMe-PA and OMe-EA were reached (as determined previously by CV). The UV-vis spectra of OMe-PA and OMe-EA have characteristic absorption bands that allow for an unambiguous identification of these structures (Figure 4, center). 
Starting with the OMe-PA the scan direction was first going towards negative potentials and then reversed. Opposite scan-directions were used to study the UV-vis spectra of the electrochemically derived intermediates of OMe-EA. This choice of scan directions resulted from the previously conducted cyclovoltammetry measurements (see SI) and were corroborated by the observation that only then changes in the UV-vis spectra are observed (Figure 4, top).

The UV-spectra recorded in dependence of the potential indicate that the OMe-PA will become - after a SET reduction - a potent hydrogen atom donor, leading to the OMe-EA after a HAT step. In this electrochemical experiment the only HAT-acceptor is the solvent. But one can envision substrates that can be reduced via HAT under these electrochemical conditions. The inverted behavior is observed for the OMe-EA. After a SET oxidation the resulting OMe-EA-R will quickly release a hydrogen atom to return to the closed shell OMe-OPA.

Conclusions. In this study the interconversion via PCET between OMe-PA and OMe-EA, i.e. the stable derivatives of the primary adduct (cationic form) and the Breslow intermediate (neutral form) have been shown by spectro-electrochemistry. Under photoredox catalysis conditions only the enaminol OMe-EA was able to quench the excited state of the photocatalyst (PC), raising the expectation that the in a dual catalysis approach the PET will be selective for OMe-EA. The PET step produced an EPR signal that has been previously characterized to be the radical from a SET oxidation step of OMe-EA. The reductive quench cycle hence is in operation. Combined quenching and EPR studies suggest, that amine additives that can undergo hydrogen atom transfer (HAT) are counterproductive as these return the OMe-EA-R into the unreactive OMe-PA. Also, experimental evidence has been found for a productive (SET reactive) ground state assembly between PC and OMe-EA as well as a counterproductive amine-OMe-EA complex. Based on these fundamental mechanistic insights synthetic applications like the dual NHC-photoredox catalysis targeting the Breslow intermediate as the reductant for the photocatalyst are currently worked on and will be published in due course. 


\section{Supporting Information}

\section{Mechanistic investigations towards a successful PET with Breslow-Intermediates}

Jenny Phan, Julia Rehbein*

Fakultät für Chemie \& Pharmazie, Universität Regensburg, Universitätsstrasse 31, 93051 Regenburg

\section{Content of SI}

EPR spectroscopy

EPR studies: additional material of control experiments................................................................. 9

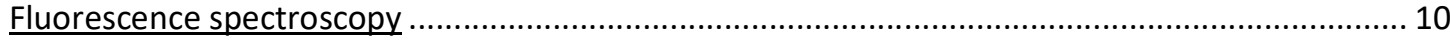

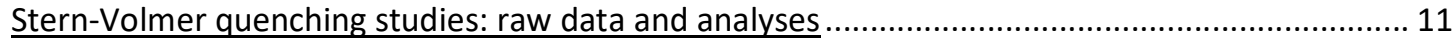

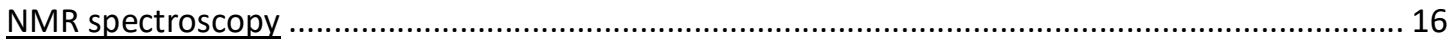

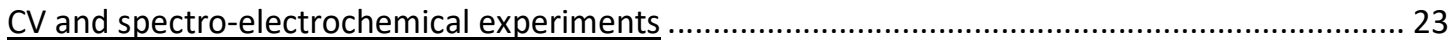

EPR spectroscopy

For the EPR measurements two spectrometers were used, a Bruker Elexsys E500 CW and a Magnettech MiniScope MS400. All samples were degassed for several cycles via freeze-pump-thaw and transferred into N2-flushed quartz-tubes (outer diameter: $4 \mathrm{~mm}$, inner diameter: $3.5 \mathrm{~mm}$ ) or into quartz tubes with PTFE-screw cap (outer diameter: $4 \mathrm{~mm}$, inner diameter: $3.2 \mathrm{~mm}$. For simultaneous irradiation, a DC Mini Jolly LED with $20 \mathrm{~W}$ maximum power has been used. Simulations of EPR-spectra was done with WinSim (Version 0.98). ${ }^{12}$

Base line correction was manually applied by analyzing the raw data in Origin ${ }^{\circledR}$ using the weighted endpoint method. ${ }^{13}$ To allow for a better comparison for spectra measured at different $\mu$ wave powers equation 1 was used (shown for a referencing to $2.631 \mathrm{~mW}$ ).

$$
\text { intensity }_{\text {new }}=\frac{\text { intensity }_{\text {old }}}{\text { conversion factor }}
$$

Eq. 1

Conversion factor: $\quad\left(\frac{\mu \text { wave power }}{2.631 \mathrm{~mW}}\right)^{0.5}$

\footnotetext{
12 D. R. Duling, J. Magn. Reson., Series B 1994, 104, 105-110, DOI: 10.1006/jmrb.1994.1062.
}

${ }^{13}$ Origin 2017G, OriginLab Corporation, Northampton, MA, USA 
EPR studies: additional material of control experiments
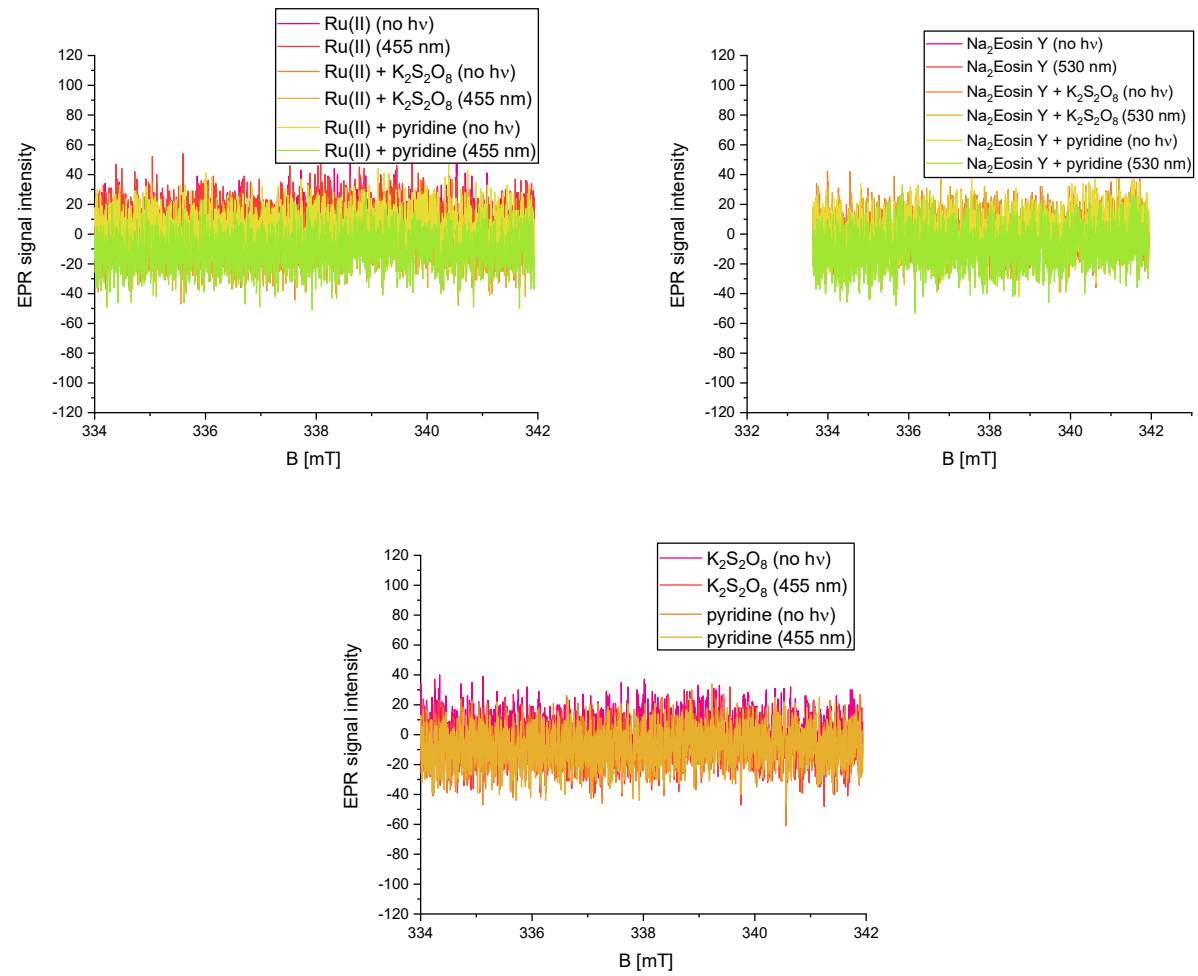

Figure SI-4. EPR-spectra of the reaction solutions containing photocatalyst $\left[\mathrm{Ru}(\mathrm{bpy})_{3}\right] \mathrm{Cl}_{2}$ or $\mathrm{Na}_{2} \mathrm{Eosin}^{\mathrm{Y}}$ (5-10 mol\%) with and without additives $\mathrm{K}_{2} \mathrm{~S}_{2} \mathrm{O}_{8}$ or pyridine (2 eq.). The sample were measured with (455/530 nm for $10 \mathrm{~min}$ ) and without irradiation. Measurement conditions: mean field: $337.784 \mathrm{mT}$, width: $8.305 \mathrm{mT}$, $\mu$ wave power: $10 \mathrm{~mW}$, time: $30 \mathrm{~s}$, modulation amplitude: $0.7 \mathrm{mT}$, receiver gain: $10 \mathrm{~dB}$. 

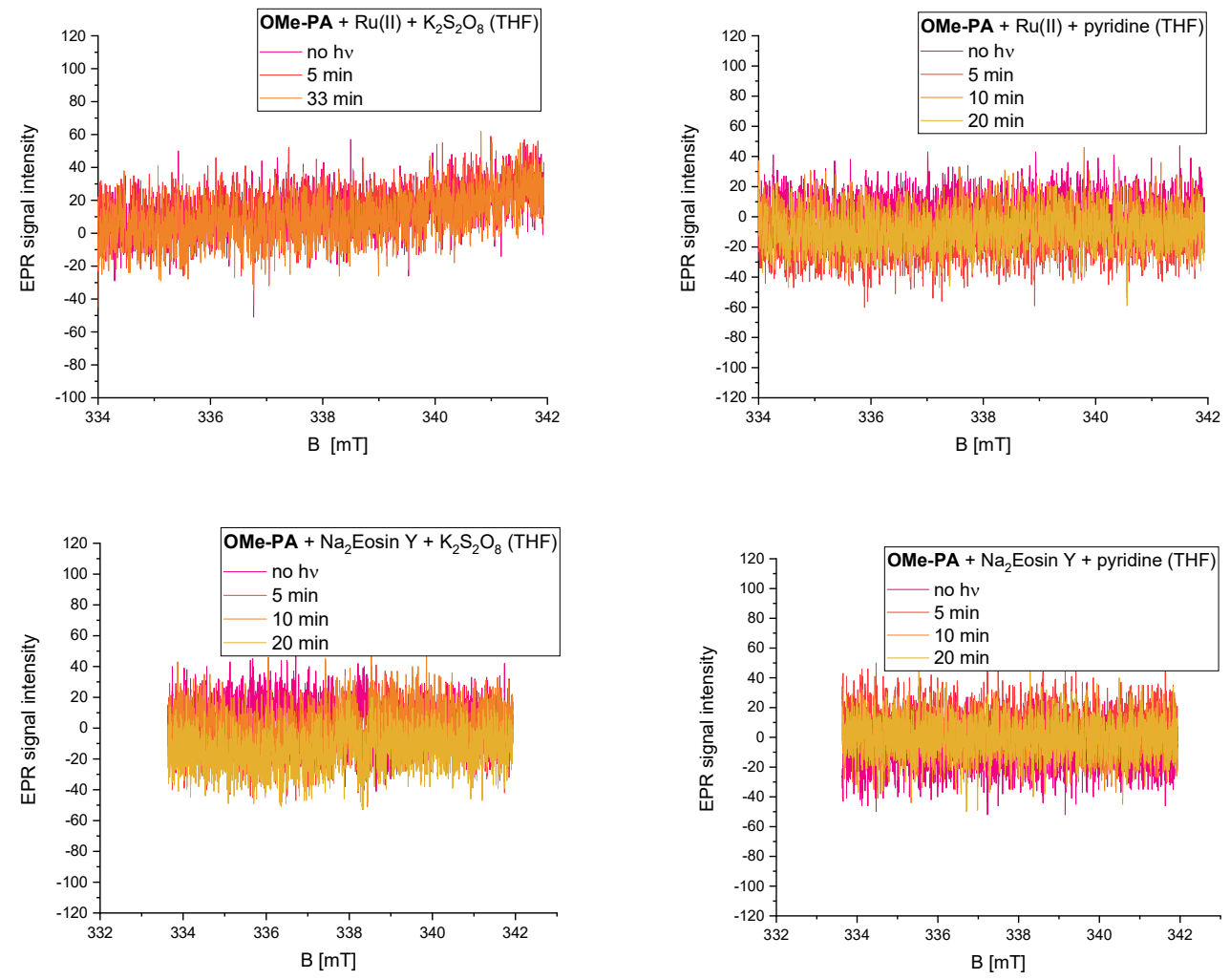

Figure SI-5. EPR-spectra of the reaction solutions containing OMe-PA (0.05 M in THF), photocatalyst $\left[\mathrm{Ru}(\mathrm{bpy})_{3}\right] \mathrm{Cl}_{2}$ or Eosin $\mathrm{Y}$ (5-10 mol\%) and $\mathrm{K}_{2} \mathrm{~S}_{2} \mathrm{O}_{8}$ or pyridine (2 eq.). The sample were measured with (455/530 nm) and without irradiation. Measurement conditions: mean field: $337.784 \mathrm{mT}$, width: $8.305 \mathrm{mT}$, $\mu$ wave power: $10 \mathrm{~mW}$, time: $30 \mathrm{~s}$, modulation amplitude: $0.7 \mathrm{mT}$, receiver gain: $10 \mathrm{~dB}$.

In this set of experiments (Figure SI-2) one clearly sees that neither with the transition metal nor with the organic dye the primary adduct OMe-PA gave rise to an EPR signal under the conditions without additive or in presence of pyridine. For $\mathrm{Na}_{2}$ Eosin $\mathrm{Y}$ the typical radical signature of the SET of the Eosin (center $339 \mathrm{mT}$ ) derived radical emerges in presence of $\mathrm{K}_{2} \mathrm{~S}_{2} \mathrm{O}_{8}$ under prolonged ( $\mathrm{t} \geq 20 \mathrm{~min}$ ) irradiation (for comparison of the see Goux et al. ${ }^{14}$ ). However, the radical concentration is significantly lower than observed with OMe-EA.

\section{Fluorescence spectroscopy}

Fluorescence spectra were recorded on a HORIBA FluoroMax -4 spectro fluorometer in a florescence cell of $d=10 \mathrm{~mm}$. The quenching constants were calculated using Eq.2. ${ }^{15}$ The Stern-Volmer constant was derived of the slope (linear fitting) from the Stern-Volmer plot.

$$
k_{\mathrm{q}}=\frac{K_{\mathrm{SV}}}{\tau}
$$

\section{Eq. 2}

\footnotetext{
${ }^{14}$ A. Goux, T. Pauport, D. Lincot, L. Dunsch ChemPhysChem 2007, 8, 926-931.

${ }^{15} \mathrm{~J}$. R. Lakowicz, Principles of Fluorescence Spectroscopy, 3. Aufl., Springer Science+Business Media, Boston, 2006.
} 
$k_{\mathrm{q}} \quad$ quenching constant $\left[\mathrm{L} \cdot(\mathrm{mol} \cdot \mathrm{s})^{-1}\right]$

Ksv Stern-Volmer constant $\left[\mathrm{L} \cdot \mathrm{mol}^{-1}\right]$

$\tau \quad$ lifetime of fluorophore $[\mathrm{s}]$

$\left[\mathrm{Ru}(\mathrm{bpy})_{3}\right]^{2+}: 350 \mathrm{~ns} ;$ Eosin Y: $\left.1.21 \mathrm{~ns}\right)^{99}$

Stern-Volmer quenching studies: raw data and analyses

Table SI-4. Table of the changes in intensities at $550 \mathrm{~nm}$ from the emission spectra of $\mathrm{Na}_{2}$ Eosin $\mathrm{Y}$ during titration with OMe-EA. Stern-Volmer plot is shown in the main text.

\begin{tabular}{|ccc|}
\hline CoMe-EA / mM & I at $550 \mathbf{n m}$ & $I_{0} / \mathbf{I}$ \\
\hline 0 & 916640 & 1 \\
2.04 & 579670 & 1.581 \\
4.03 & 540600 & 1.696 \\
12.13 & 479460 & 1.912 \\
31.82 & 320650 & 2.859 \\
50.88 & 216370 & 4.236 \\
69.34 & 155730 & 5.886 \\
87.23 & 112370 & 8.157
\end{tabular}

Table SI-5. Table of the changes in intensities at $610 \mathrm{~nm}$ from the emission spectra of $\left[\mathbf{R u}(\mathbf{b p y})_{3}\right] \mathbf{C l}_{\mathbf{2}}$ during titration with OMe-EA. Potted raw data (also shown in the main text) and Stern-Volmer graph are shown below (Figure SI-3).

\begin{tabular}{|ccc|}
\hline CoMe-PA / mM & I bei $610 \mathrm{~nm}$ & $\mathrm{I}_{0} / \mathbf{I}$ \\
\hline 0 & 1124700 & 1 \\
0.42 & 1580890 & 0.711 \\
1.27 & 2150290 & 0.523 \\
1.69 & 1431900 & 0.785 \\
2.11 & 1195680 & 0.941 \\
2.54 & 1052990 & 1.068 \\
3.38 & 983050 & 1.144 \\
4.22 & 847170 & 1.328 \\
5.90 & 755670 & 1.488 \\
7.58 & 677990 & 1.659 \\
\hline
\end{tabular}



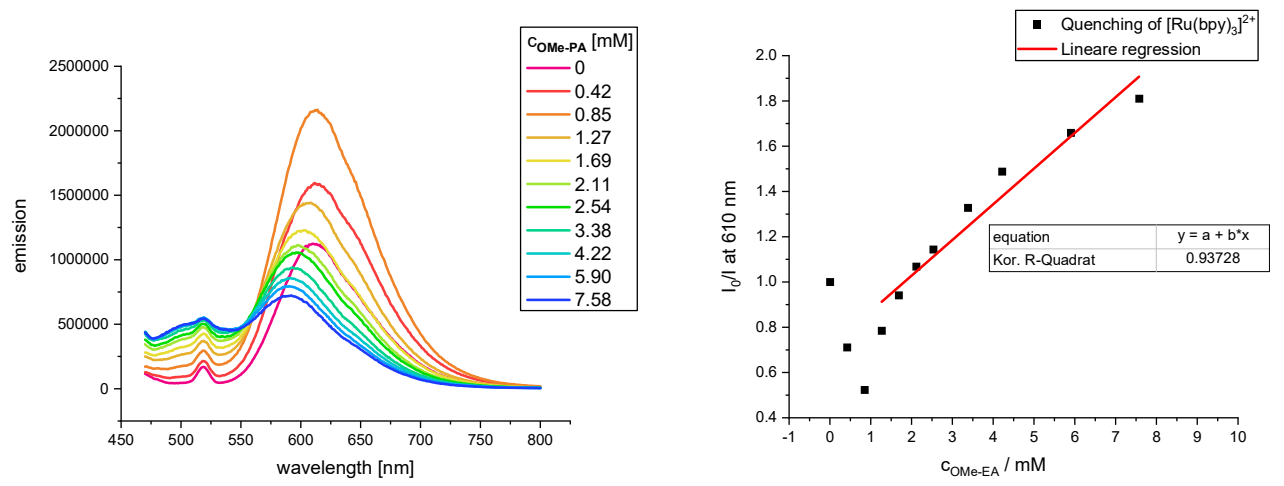

Figure SI-6. Left: Quenching of the fluorescence of $\left[\mathrm{Ru}(\mathbf{b p y})_{3}\right] \mathbf{C l}_{\mathbf{2}}$ as a function of Come-EA in THF. Irradiation at 450 $\mathrm{nm}$ (slid width: $6 \mathrm{~nm}$ ), emission: 470-800 nm (slid width: $6 \mathrm{~nm}$ ). Right: Stern-Volmer diagram fitted with a linear function $\left(R^{2}=0.94\right)$ yielding $\mathrm{K}$ value as shown in main text.

Table SI-6. Table of the changes in intensities at $610 \mathrm{~nm}$ from the emission spectra of $\left[\mathbf{R u}(\mathbf{b p y})_{3}\right] \mathbf{C l}_{2}$ during titration with DIPEA. Potted raw data and Stern-Volmer graph are shown below (Figure SI-4).

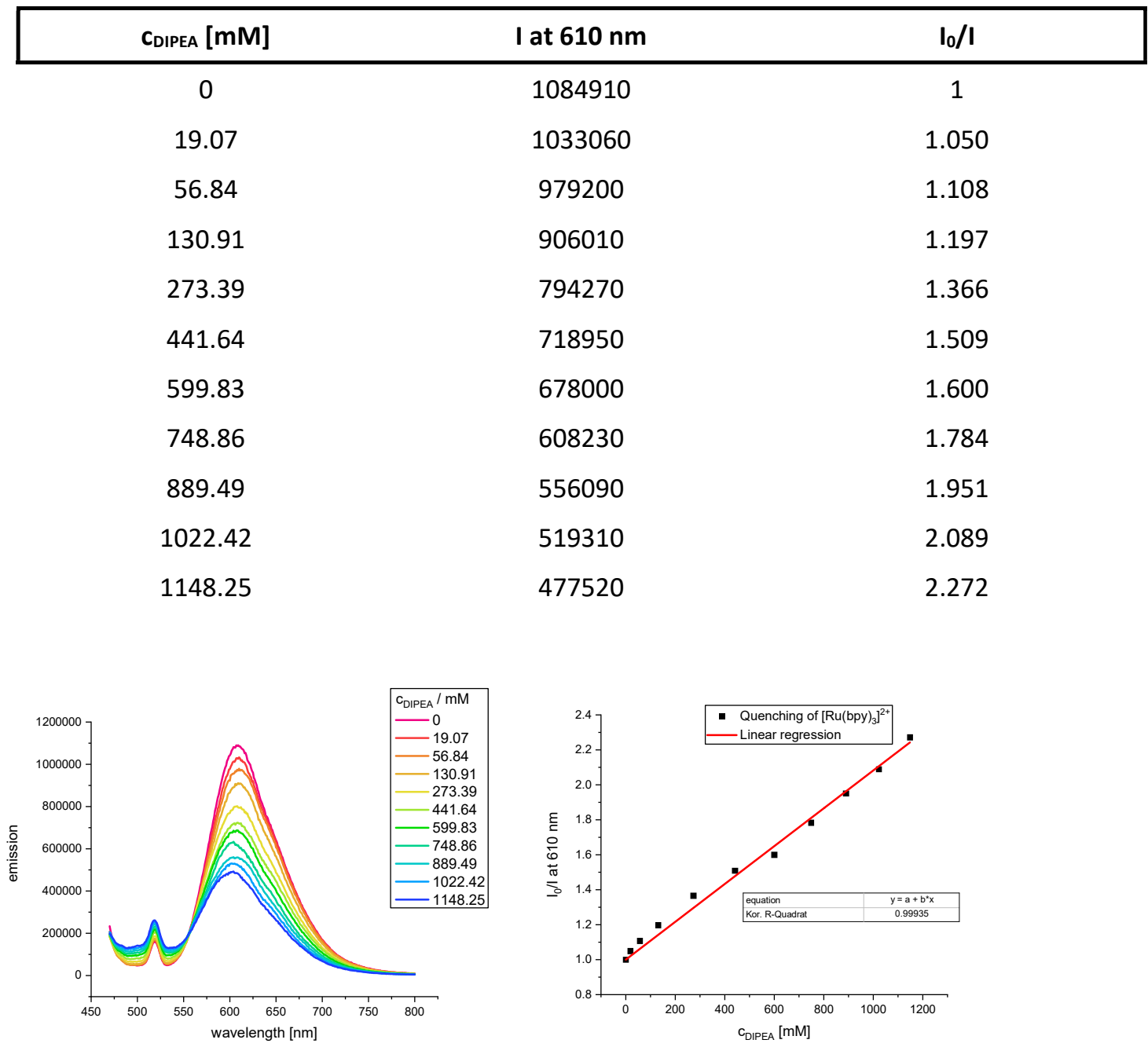

Figure SI-7. Left: Quenching of the fluorescence of $\left[\mathrm{Ru}(\mathbf{b p y})_{3}\right] \mathrm{Cl}_{2}$ as a function of CDIPEA in THF. Irradiation at 450 $\mathrm{nm}$ (slid width: $6 \mathrm{~nm}$ ), emission: 470-800 nm (slid width: $6 \mathrm{~nm}$ ). Right: Stern-Volmer diagram fitted with a linear function $\left(R^{2}=0.99\right)$ yielding $\mathrm{K}$ value as shown in main text. 
Table SI-7. Table of the changes in intensities at $612 \mathrm{~nm}$ from the emission spectra of $\left[\mathbf{R u}(\mathbf{b p y})_{3}\right] \mathrm{Cl}_{2}$ during titration with m-DNB. Potted raw data and Stern-Volmer graph are shown below (Figure SI-5).

\begin{tabular}{|ccc|}
\hline $\mathbf{C}_{\text {mDNB }}[\mathrm{mM}]$ & $\mathrm{I}$ at $\mathbf{6 1 2} \mathbf{n m}$ & $\mathrm{I} / \mathrm{I}$ \\
\hline 0 & 1284080 & 1 \\
0.40 & 1458470 & 0.880 \\
0.80 & 1369650 & 0.938 \\
1.20 & 1310570 & 0.980 \\
1.60 & 1271340 & 1.010 \\
2.40 & 1172310 & 1.095 \\
3.19 & 1109070 & 1.158 \\
3.99 & 1038650 & 1.236 \\
5.97 & 946140 & 1.357 \\
9.92 & 811960 & 1.581 \\
19.67 & 656990 & 1.954
\end{tabular}
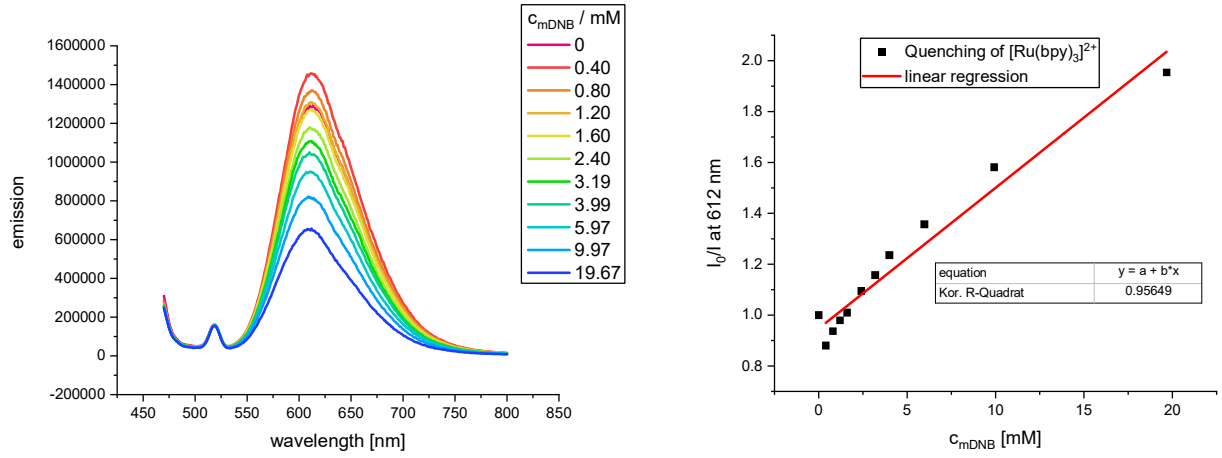

Figure SI-8. Left: Quenching of the fluorescence of $\left[\mathrm{Ru}(\mathrm{bpy})_{3}\right] \mathrm{Cl}_{2}$ as a function of $\mathrm{CmDNB}_{\mathrm{mB}}$ in THF. Irradiation at 450 $\mathrm{nm}$ (slid width: $6 \mathrm{~nm}$ ), emission: 470-800 nm (slid width: $6 \mathrm{~nm}$ ). Right: Stern-Volmer diagram fitted with a linear function $\left(R^{2}=0.96\right)$ yielding $\mathrm{K}$ value as shown in main text. 
Table SI-8. Table of the changes in intensities at $545 \mathrm{~nm}$ from the emission spectra of $\mathrm{Na}_{2}$-Eosin $\mathrm{Y}$ during titration with DIPEA. Potted raw data and Stern-Volmer graph are shown below (Figure SI-6).

\begin{tabular}{|ccc|}
\hline CDIPEA $[\mathrm{mM}]$ & I at $545 \mathbf{~ n m}$ & $\mathrm{I} / \mathrm{I}$ \\
\hline 0 & 906930 & 1 \\
9.55 & 1460220 & 0.621 \\
19.07 & 1620270 & 0.560 \\
28.56 & 1655260 & 0.548 \\
38.02 & 1683620 & 0.539 \\
47.45 & 1682060 & 0.539 \\
56.84 & 1693540 & 0,536 \\
75.54 & 1666230 & 0.544 \\
94.12 & 1651330 & 0.549 \\
185.2 & 1510030 & 0.601 \\
273.39 & 1359400 & 0.667 \\
358.83 & 1243100 & 0.730 \\
441.64 & 1141240 & 0.795 \\
521.93 & 1054480 & 0.860
\end{tabular}
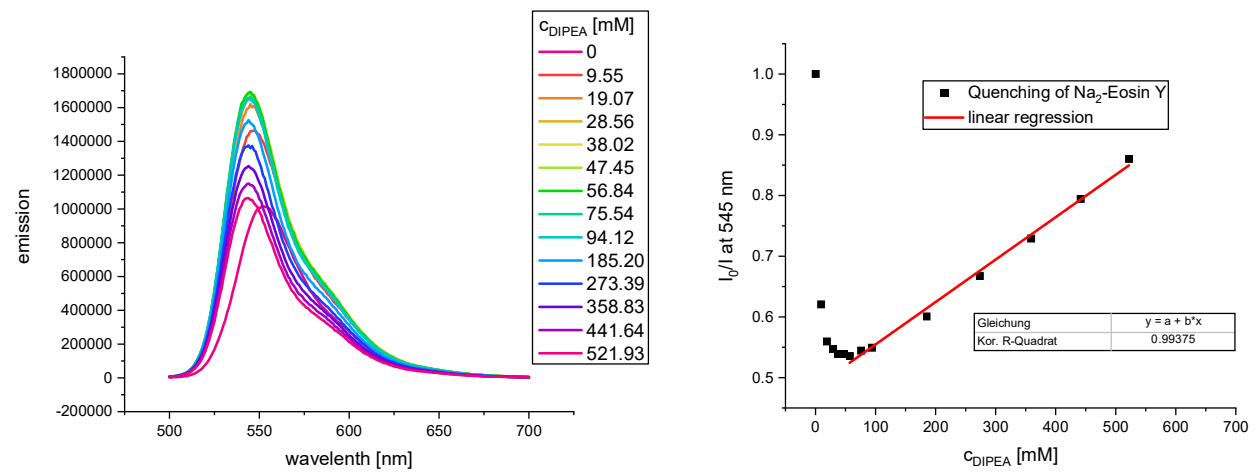

Figure SI-9. Left: Quenching of the fluorescence of Na2-Eosin $\mathbf{Y}$ as a function of CmDIPEA in THF. Irradiation at 480 $\mathrm{nm}$ (slid width: $6 \mathrm{~nm}$ ), emission: 500-700 nm (slid width: $1 \mathrm{~nm}$ ). Right: Stern-Volmer diagram fitted with a linear function $\left(R^{2}=0.99\right)$ yielding $\mathrm{K}$ value as shown in main text. Interestingly the fluorescence increases and shifts on the first titration points. This is quite similar to the results with $\left[\mathrm{Ru}(\mathrm{bipy})_{3}\right] \mathrm{Cl}_{2}$. So in both cases there seems to be an assembly of the PC (in this case with itself) that is broken up by the addition of the amine base or the quencher in general. 
Table SI-9. Table of the changes in intensities at $552 \mathrm{~nm}$ from the emission spectra of $\mathrm{Na}_{2}$-Eosin $\mathrm{Y}$ during titration with $\mathbf{m}$-DNB. Potted raw data and Stern-Volmer graph are shown below (Figure SI-7).

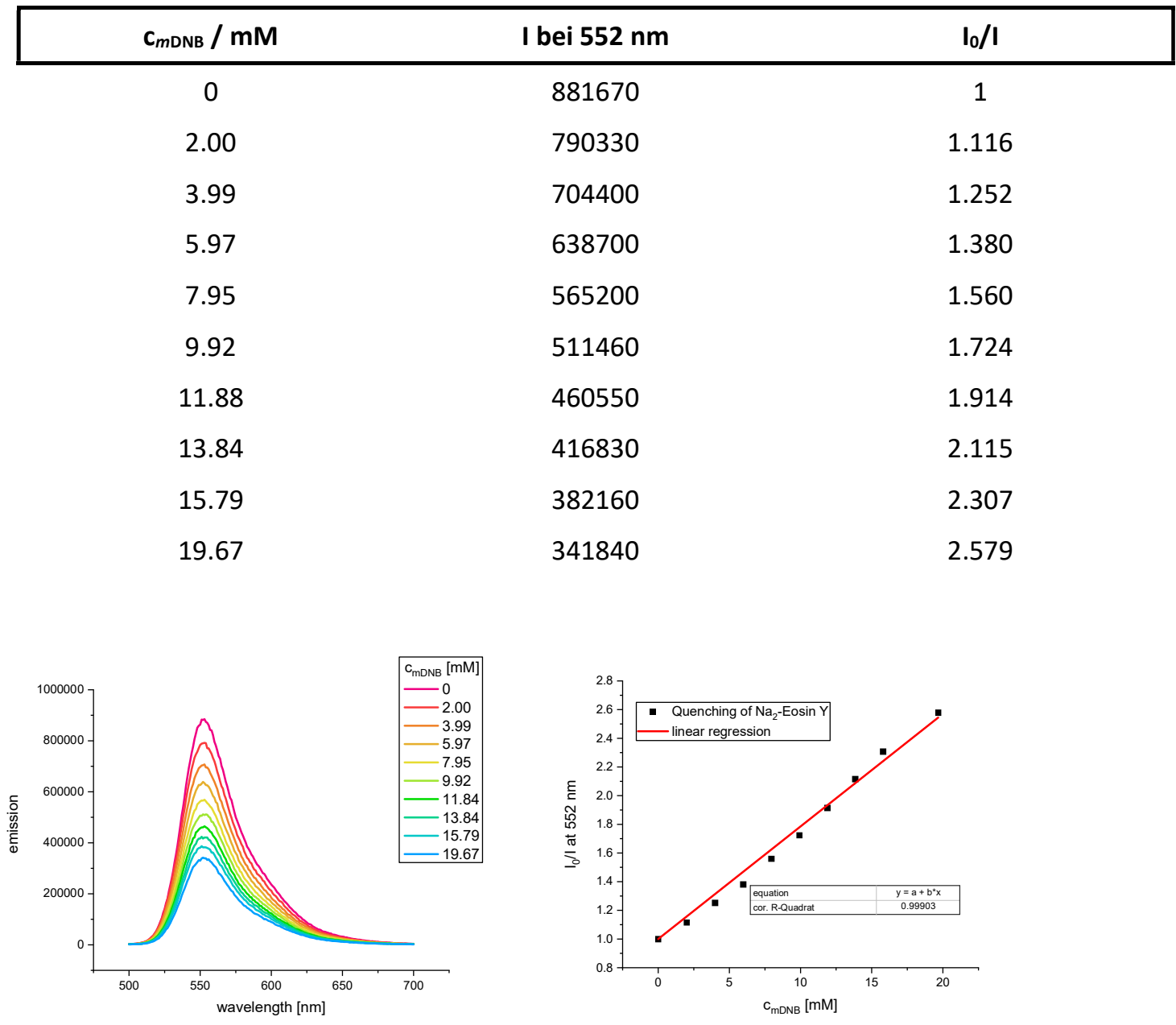

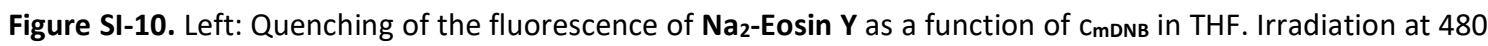
$\mathrm{nm}$ (slid width: $6 \mathrm{~nm}$ ), emission: 500-700 nm (slid width: $1 \mathrm{~nm}$ ). Right: Stern-Volmer diagram fitted with a linear function $\left(R^{2}=0.99\right)$ yielding $\mathrm{K}$ value as shown in main text.

Table SI-10. Table of the changes in intensities at $520 \mathrm{~nm}$ from the emission spectra of OMe-EA during titration with DIPEA. Potted raw data and Stern-Volmer graph are shown in the main text.

\begin{tabular}{|ccc|}
\hline$C_{\text {DIPEA }}[\mathrm{mM}]$ & I at $\mathbf{5 2 0} \mathbf{~ n m}$ & $\mathbf{I}_{\mathbf{0}} / \mathbf{I}$ \\
\hline 0 & 209350 & 1 \\
19.07 & 224470 & 0.933 \\
38.02 & 227160 & 0.922 \\
56.84 & 229720 & 0.911 \\
94.12 & 232610 & 0.900 \\
185.2 & 241090 & 0.868 \\
358.83 & 264450 & 0.792 \\
675.44 & 299610 & 0.699
\end{tabular}


NMR spectroscopy

NMR spectra were recorded at a Bruker Fourier HD 300, Avance 300 and Avance III HD 400. Chemical shifts $\delta$ are reported in ppm and are relative to the the signal of Tetramethylsilan ( ${ }^{1} \mathrm{H}$ NMR: $0.00 \mathrm{ppm}$ ) or the non-deuterated traces of the NMR solvent (Chloroform- $d\left({ }^{1} \mathrm{H}-\mathrm{NMR}: 7.26 \mathrm{ppm},{ }^{13} \mathrm{C}-\mathrm{NMR}\right.$ : $77.16 \mathrm{ppm}$ ). Multiplicities of the singnals are reported as $s=$ singulet, $d=$ dublet, $t=$ triplet, $q=$ quartet, quint = quintet, $d d=$ doublet of doublet,$d t=$ doublet of triplet, $t d=$ triplet of doublet, qd = quartet of doublet, $\mathrm{m}=$ multiplet, $\mathrm{br}=$ broad signal.

Synthesis of the OMe-EA and OMe-PA have been reported previously by us (see main text, citations $5 a, b)$ In the following the ${ }^{1} \mathrm{H}$ and ${ }^{13} \mathrm{C}$ spectra are provided to ensure identity.

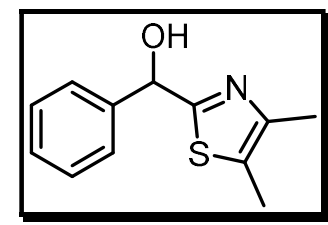

1

$\mathrm{C}_{12} \mathrm{H}_{13} \mathrm{NOS}$

$219.30 \mathrm{~g} \cdot \mathrm{mol}^{-1}$

Yield

white solid (7.8 g, $36 \mathrm{mmol}, 73 \%)$.

${ }^{1}$ H NMR

(400 MHz, $\left.\mathrm{CDCl}_{3}\right): \delta=7.39-7.37\left(\mathrm{~m}, 2 \mathrm{H}, 2 \times \mathrm{H}_{\mathrm{ar}}\right), 7.28-7.17\left(\mathrm{~m}, 3 \mathrm{H}, 3 \times \mathrm{H}_{\mathrm{ar}}\right), 5.85$ (s, 1H, CH), $4.59(\mathrm{br} \mathrm{s}, 1 \mathrm{H}, \mathrm{OH}), 2.18\left(\mathrm{~s}, 3 \mathrm{H}, \mathrm{CH}_{3}\right), 2.16\left(\mathrm{~s}, 3 \mathrm{H}, \mathrm{CH}_{3}\right)$.

${ }^{13} \mathrm{C}$ NMR

$\left(100 \mathrm{MHz}, \mathrm{CDCl}_{3}\right): \delta=169.9$ (NCS), $147.5\left(\mathrm{C}_{\mathrm{ar}}\right), 141.9\left(\mathrm{C}_{\mathrm{ar}}\right), 128.6\left(\mathrm{C}_{\mathrm{ar}}\right), 128.3$

$\left(\mathrm{C}_{\mathrm{ar}}\right), 127.2\left(\mathrm{C}_{\mathrm{ar}}\right), 126.6(\mathrm{Car}), 73.4(\mathrm{CH}), 14.6\left(\mathrm{CH}_{3}\right), 11.4\left(\mathrm{CH}_{3}\right)$. 


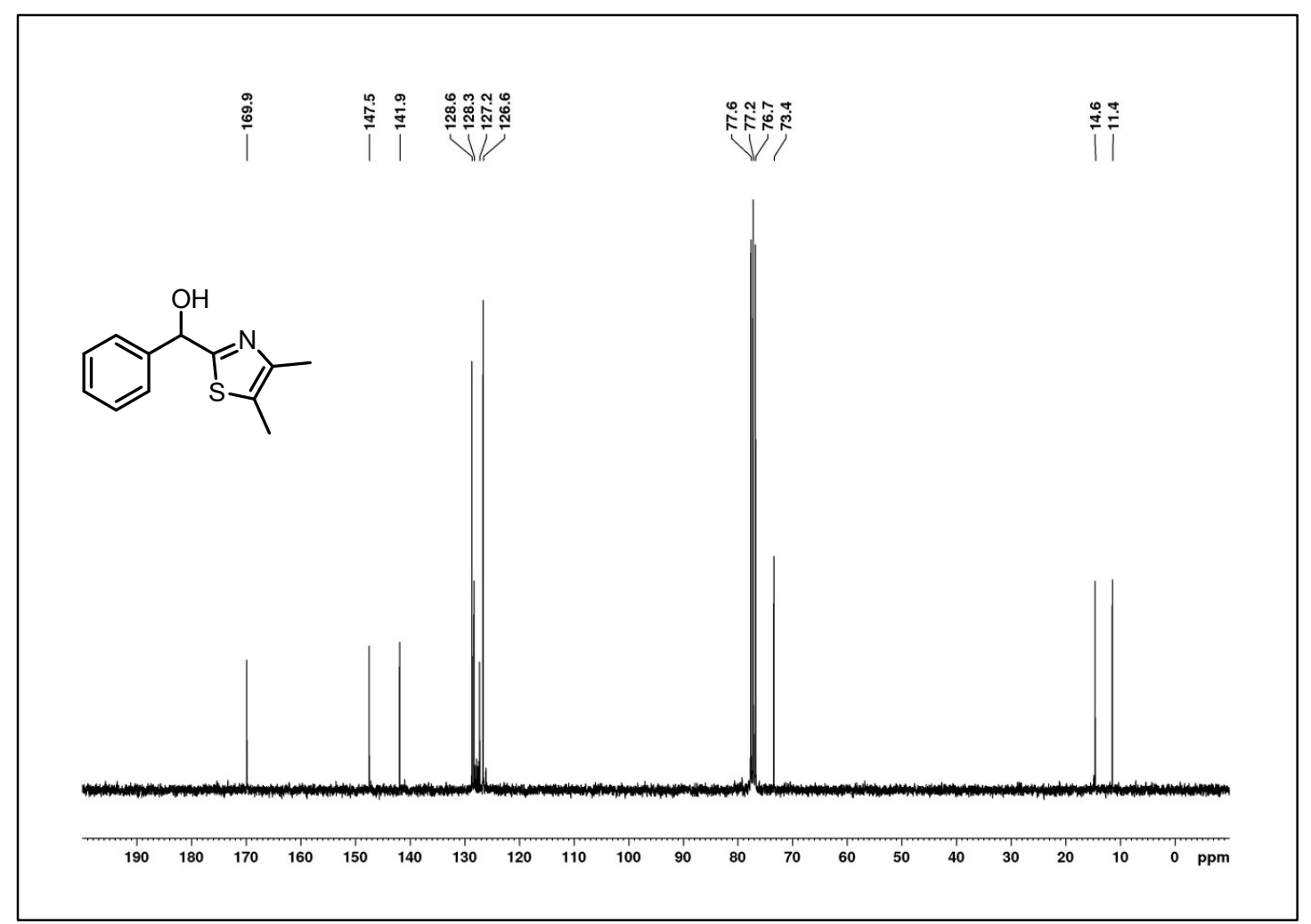

Figure SI-11. ${ }^{13} \mathrm{C}-\mathrm{NMR}-S p e k t r u m$ von 1 in $\mathrm{CDCl}_{3}(75 \mathrm{MHz})$.

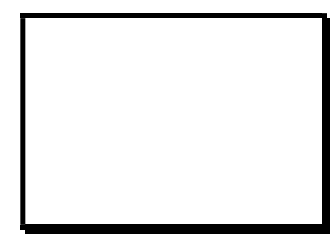

2

$\mathrm{C}_{13} \mathrm{H}_{15} \mathrm{NOS}$

$233.33 \mathrm{~g} \cdot \mathrm{mol}^{-1}$

Yield

yellow liquid (7.9 g, $34 \mathrm{mmol}, 97 \%)$.

${ }^{1} \mathrm{H}$ NMR

$\left(400 \mathrm{MHz} \mathrm{CDCl}_{3}\right): \delta=7.44-7.42\left(\mathrm{~m}, 2 \mathrm{H}, \mathrm{H}_{\mathrm{ar}}\right), 7.34-7.23\left(\mathrm{~m}, 3 \mathrm{H}, \mathrm{H}_{\mathrm{ar}}\right), 3.42(\mathrm{~s}$, $\left.3 \mathrm{H}, \mathrm{OCH}_{3}\right), 2.26\left(\mathrm{~s}, 6 \mathrm{H}, 2 \times \mathrm{CH}_{3}\right)$.

${ }^{13}$ C NMR

$\left(100 \mathrm{MHz}, \mathrm{CDCl}_{3}\right): \delta=167.6$ (NCS), $147.8\left(\mathrm{C}_{\mathrm{ar}}\right), 140.0\left(\mathrm{C}_{\mathrm{ar}}\right), 128.7\left(\mathrm{C}_{\mathrm{ar}}\right), 128.3$ $\left(\mathrm{C}_{\mathrm{ar}}\right), 127.2\left(\mathrm{C}_{\mathrm{ar}}\right), 126.9(\mathrm{Car}), 83.2(\mathrm{CH}), 57.5\left(\mathrm{OCH}_{3}\right), 14.8\left(\mathrm{CH}_{3}\right), 11.4\left(\mathrm{CH}_{3}\right)$. 


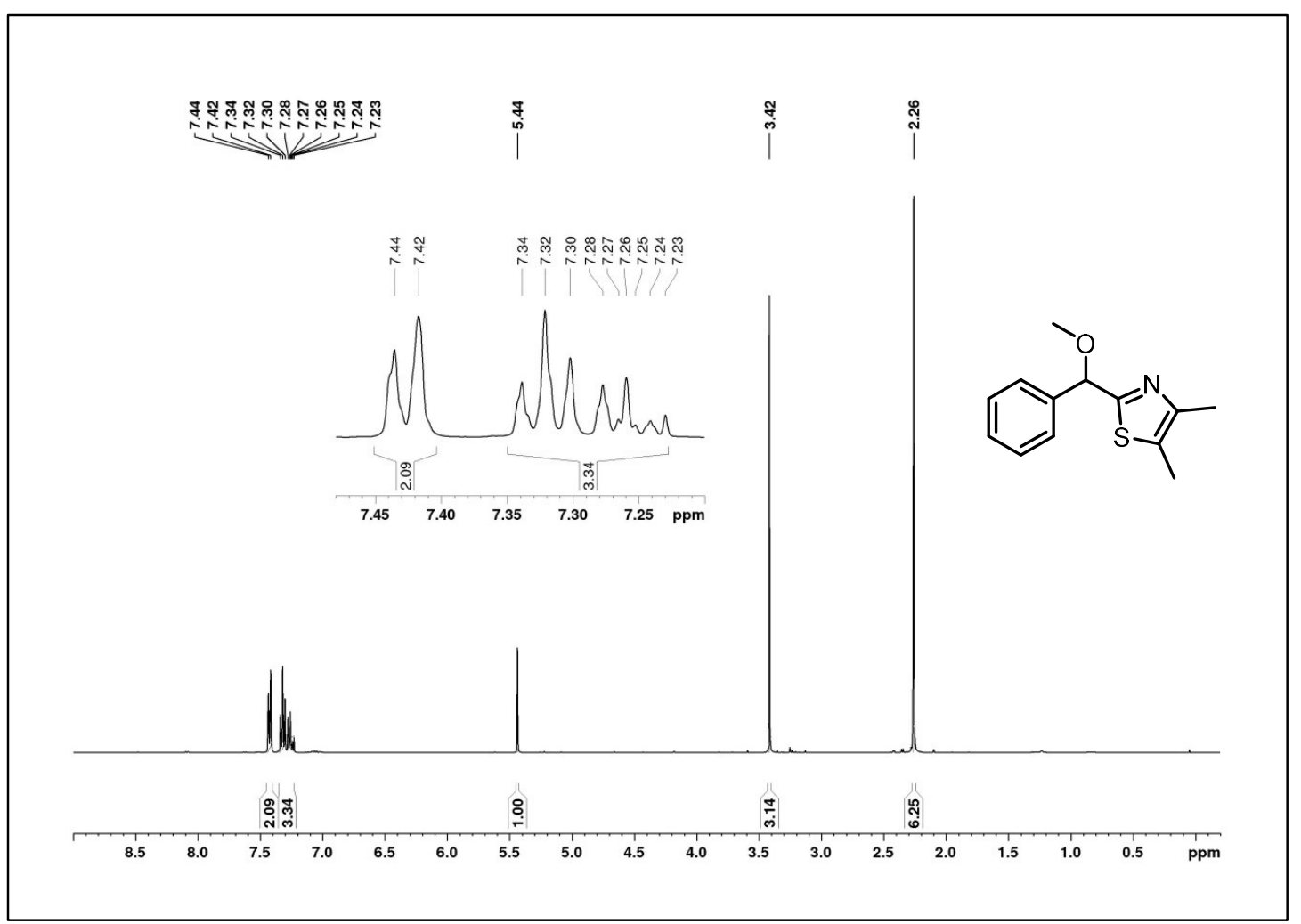

Figure SI-12. ${ }^{1} \mathrm{H} \mathrm{NMR}$ of 2 in $\mathrm{CDCl}_{3}(400 \mathrm{MHz})$.

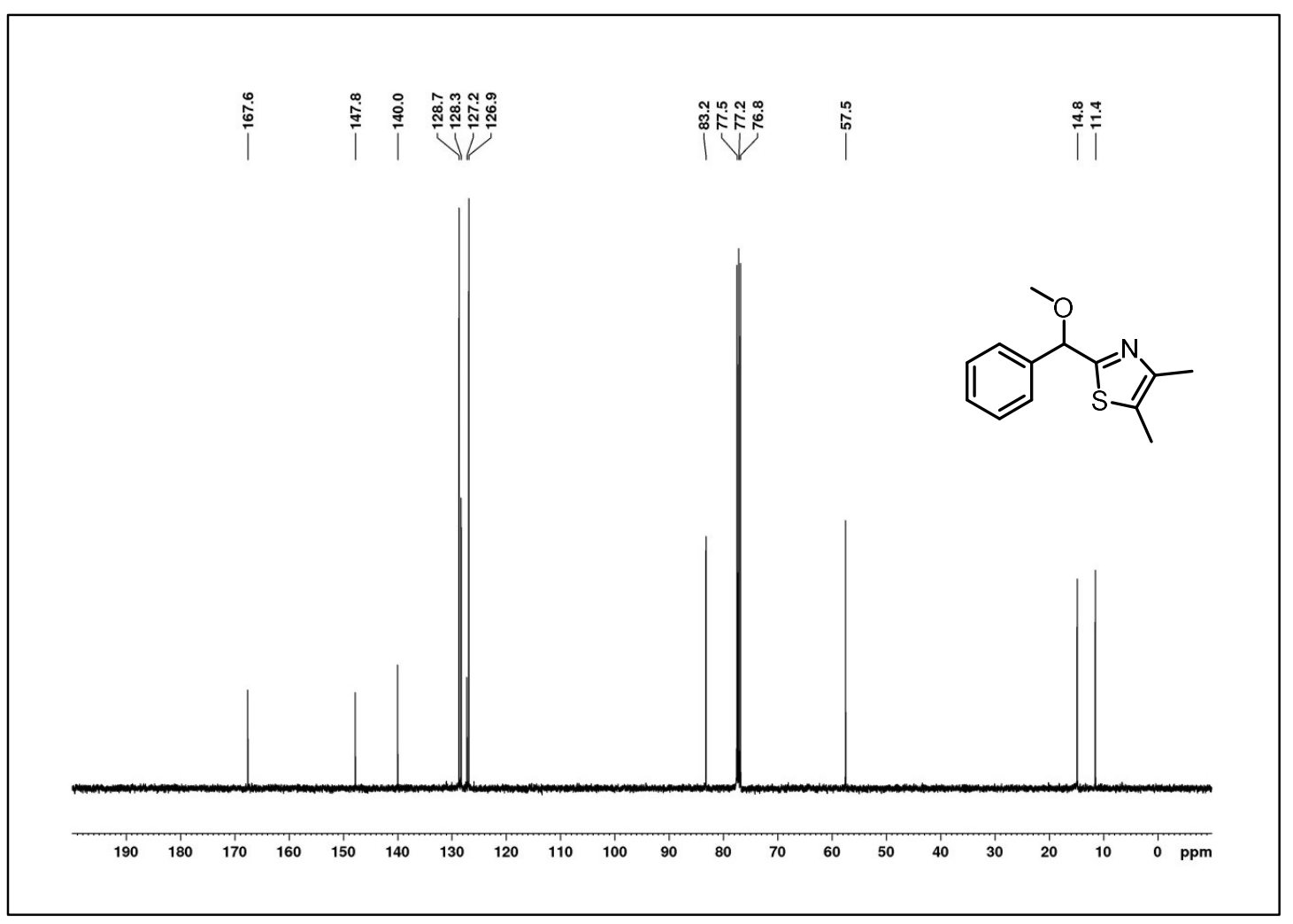

Figure $\mathrm{SI}-13 .{ }^{13} \mathrm{C} \mathrm{NMR}$ of 2 in $\mathrm{CDCl}_{3}(100 \mathrm{MHz})$. 


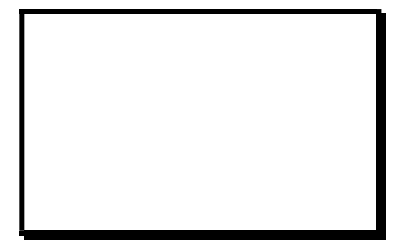

OMe-PA

$\mathrm{C}_{14} \mathrm{H}_{18} \mathrm{BF}_{4} \mathrm{NOS}$

$335.17 \mathrm{~g} \cdot \mathrm{mol}^{-1}$

Yield

oil (11.3 g, $34 \mathrm{mmol}$, quantitative).

${ }^{1} \mathrm{H}$ NMR

$\left(400 \mathrm{MHz}, \mathrm{CDCl}_{3}\right): \delta=7.43\left(\mathrm{~s}, 5 \mathrm{H}, 5 \times \mathrm{H}_{\mathrm{ar}}\right), 5.90(\mathrm{~s}, 1 \mathrm{H}, \mathrm{CH}), 3.81\left(\mathrm{~s}, 3 \mathrm{H}, \mathrm{OCH}_{3}\right)$, $3.44\left(\mathrm{~s}, 3 \mathrm{H}, \mathrm{NCH}_{3}\right), 2.44\left(\mathrm{~s}, 3 \mathrm{H}, \mathrm{CH}_{3}\right), 2.38\left(\mathrm{~s}, 3 \mathrm{H}, \mathrm{CH}_{3}\right)$.

${ }^{13} \mathrm{C}$ NMR

(100 MHz, $\left.\mathrm{CDCl}_{3}\right): \delta=172.2$ (NCS), $144.0\left(\mathrm{C}_{\mathrm{ar}}\right), 134.1\left(\mathrm{C}_{\mathrm{ar}}\right), 130.8\left(\mathrm{C}_{\mathrm{ar}}\right), 130.5$

$\left(\mathrm{C}_{\mathrm{ar}}\right), 129.6\left(\mathrm{C}_{\mathrm{ar}}\right), 128.4\left(\mathrm{C}_{\mathrm{ar}}\right), 78.8(\mathrm{CH}), 57.7\left(\mathrm{NCH}_{3}\right), 38.3\left(\mathrm{OCH}_{3}\right), 12.3\left(\mathrm{CH}_{3}\right)$, $12.0\left(\mathrm{CH}_{3}\right)$.

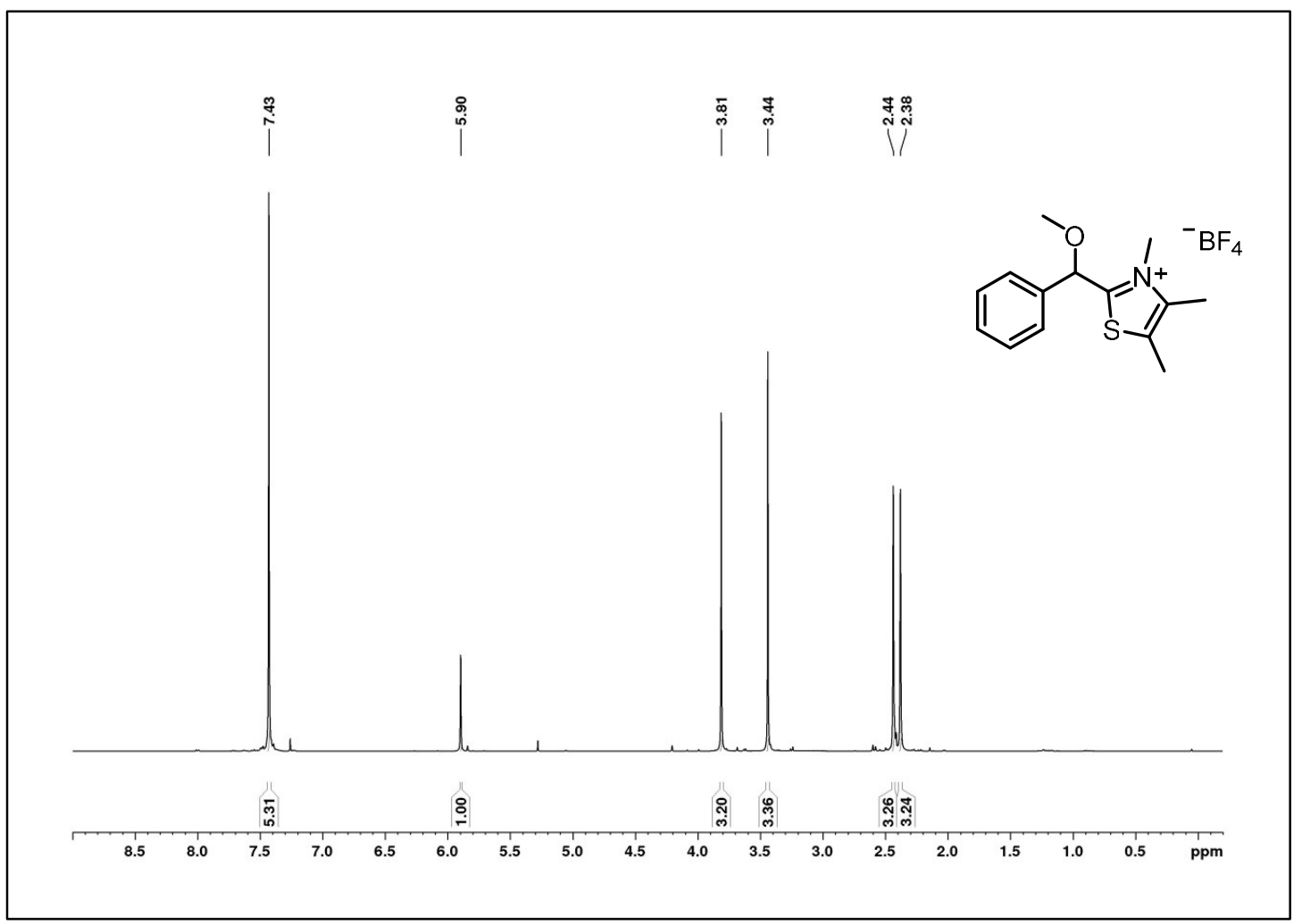

Figure SI-14. ${ }^{1} \mathrm{H}$ NMR of OMe-PA in $\mathrm{CDCl}_{3}(400 \mathrm{MHz})$. 


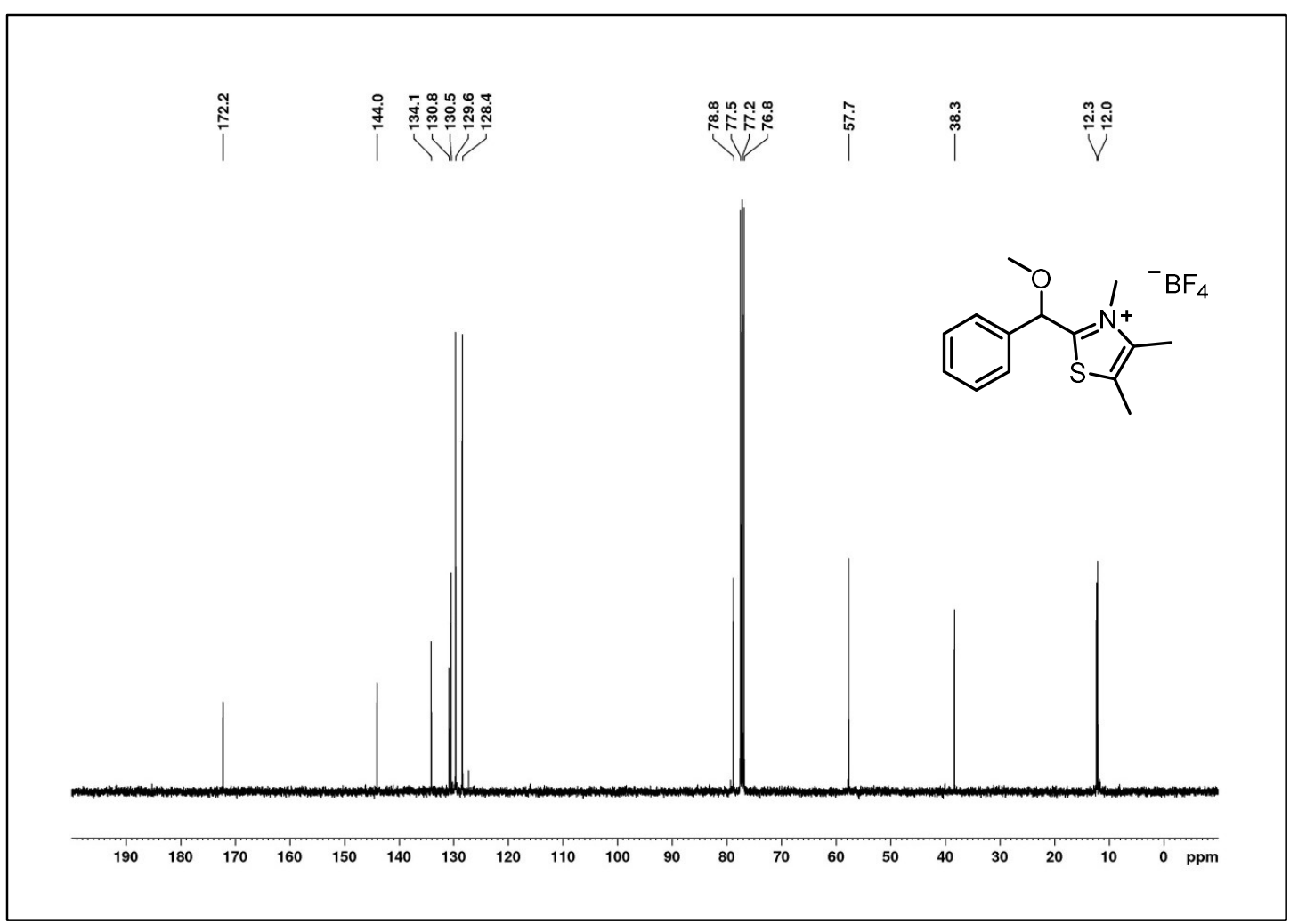

Figure SI-15. ${ }^{13} \mathrm{C}$ NMR of OMe-PA in $\mathrm{CDCl}_{3}(100 \mathrm{MHz})$.

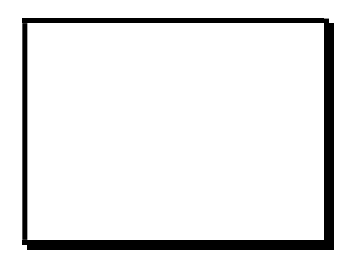

OMe-EA

$\mathrm{C}_{14} \mathrm{H}_{17} \mathrm{NOS}$

$247.36 \mathrm{~g} \cdot \mathrm{mol}^{-1}$

Yield

oil (11.3 g, $34 \mathrm{mmol}$, quantitative).

${ }^{1}$ H NMR

(400 MHz, $\left.\mathrm{CDCl}_{3}\right): \delta=7.83-7.80\left(\mathrm{~m}, 2 \mathrm{H}, \mathrm{H}_{\mathrm{ar}}\right), 7.44-7.42 *\left(\mathrm{~m}, 2 \mathrm{H}, \mathrm{H}_{\mathrm{ar}}\right)$, 7.32-7.28 (m, 2H, $\left.\mathrm{H}_{\mathrm{ar}}\right), 7.23-7.19^{*}\left(\mathrm{~m}, 2 \mathrm{H}, \mathrm{H}_{\mathrm{ar}}\right), 7.03-6.96\left(\mathrm{~m}, 1 \mathrm{H}^{*}+1 \mathrm{H}\right.$, $\left.\mathrm{H}_{\mathrm{ar}} * \mathrm{H}_{\mathrm{ar}}\right), 3.51^{*}\left(\mathrm{~s}, 3 \mathrm{H}, \mathrm{OCH}_{3}\right), 3.35\left(\mathrm{~s}, 3 \mathrm{H}, \mathrm{OCH}_{3}\right), 2.99\left(\mathrm{~s}, 3 \mathrm{H}, \mathrm{NCH}_{3}\right), 2.42 *(\mathrm{~s}$, $\left.3 \mathrm{H}, \mathrm{NCH}_{3}\right), 1.66^{*}\left(\mathrm{~s}, 3 \mathrm{H}, \mathrm{CH}_{3}\right), 1.58\left(\mathrm{~s}, 3 \mathrm{H}, \mathrm{CH}_{3}\right), 1.30\left(\mathrm{~s}, 3 \mathrm{H}^{*}+3 \mathrm{H}, \mathrm{CH}_{3}{ }^{*}+\mathrm{CH}_{3}\right)$. *main stereoisomer. 


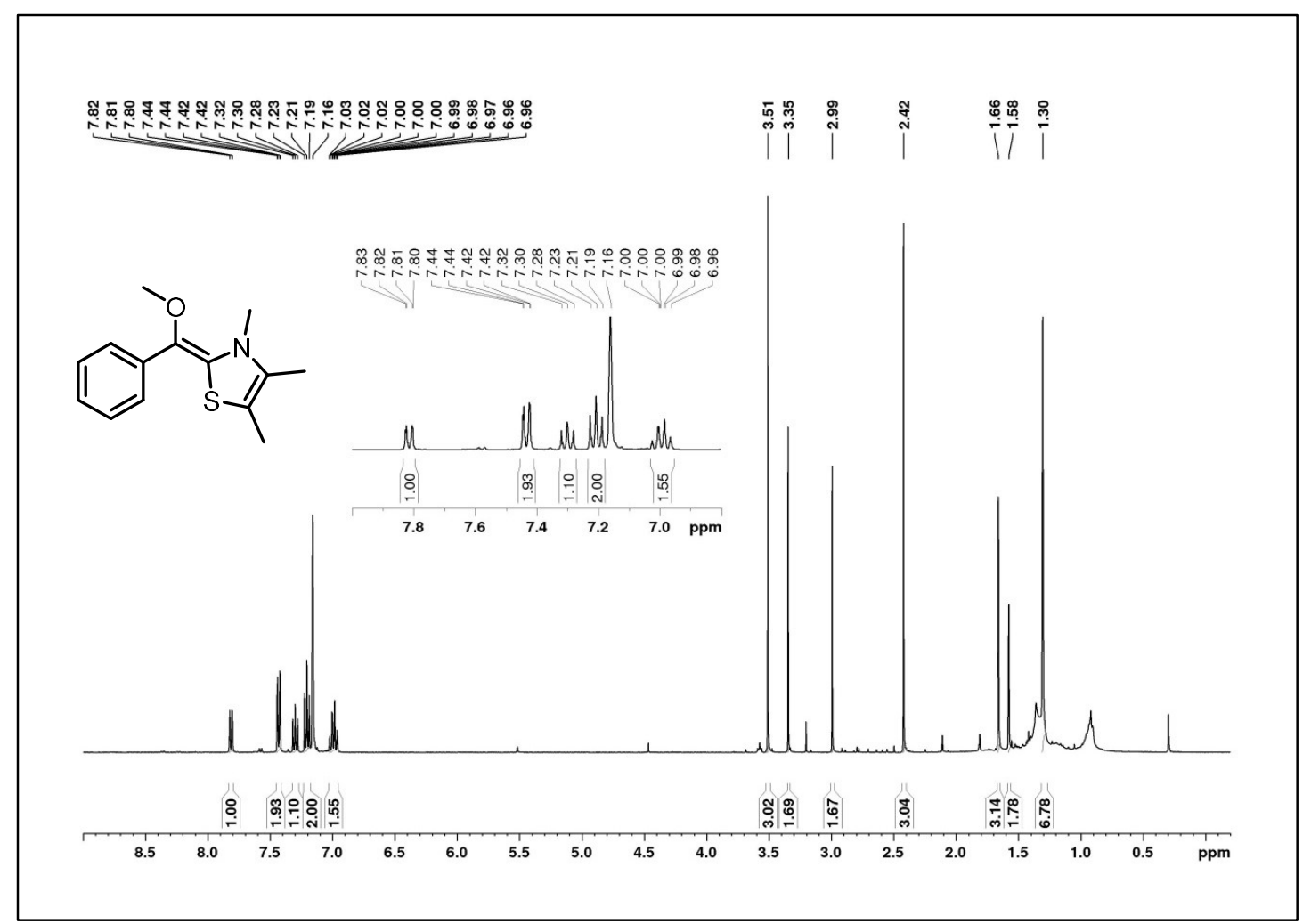

Figure SI-16. ${ }^{1} \mathrm{H}$ NMR of OMe-EA in $\mathrm{C}_{6} \mathrm{D}_{6}(400 \mathrm{MHz})$. 

Cyclovoltammetry was done with an Autolab PGSTAT302N potentiostat (Metrohm) under Aratmosphere. The following electrodes have been used: glass-carbon electrode as working electrode, Pt wire as counter electrode and $\mathrm{Ag}$ wire as pseudo-reference electrode. Tetrabutylammoniumtetrafluoroborat served as electrolyte and ferrocene was used as an internal standard to determine the peak potentials. The samples were degassed by bubbling Ar through the solution.

Table SI-11. Summary of the measured peak potentials of OMe-PA and OMe-EA (ferrocene as reference).

\begin{tabular}{|c|cc|cc|}
\hline \multirow{2}{*}{} & \multicolumn{4}{|c|}{ peak potential [V] } \\
\cline { 2 - 5 } & OMe-PA & ferrocene & OMe-EA & ferrocene \\
\hline \multirow{2}{*}{$\begin{array}{c}\text { positive scan } \\
\text { direction }\end{array}$} & -1.662 & 0.584 & -1.068 & 0.821 \\
& - & 0.816 & -0.680 & 0.977 \\
\hline \multirow{2}{*}{$\begin{array}{c}\text { negative scan } \\
\text { direction }\end{array}$} & -1.682 & - & 0.690 & - \\
& 0.252 & 0.554 & - & - \\
& 0.423 & 0.806 & - & -
\end{tabular}
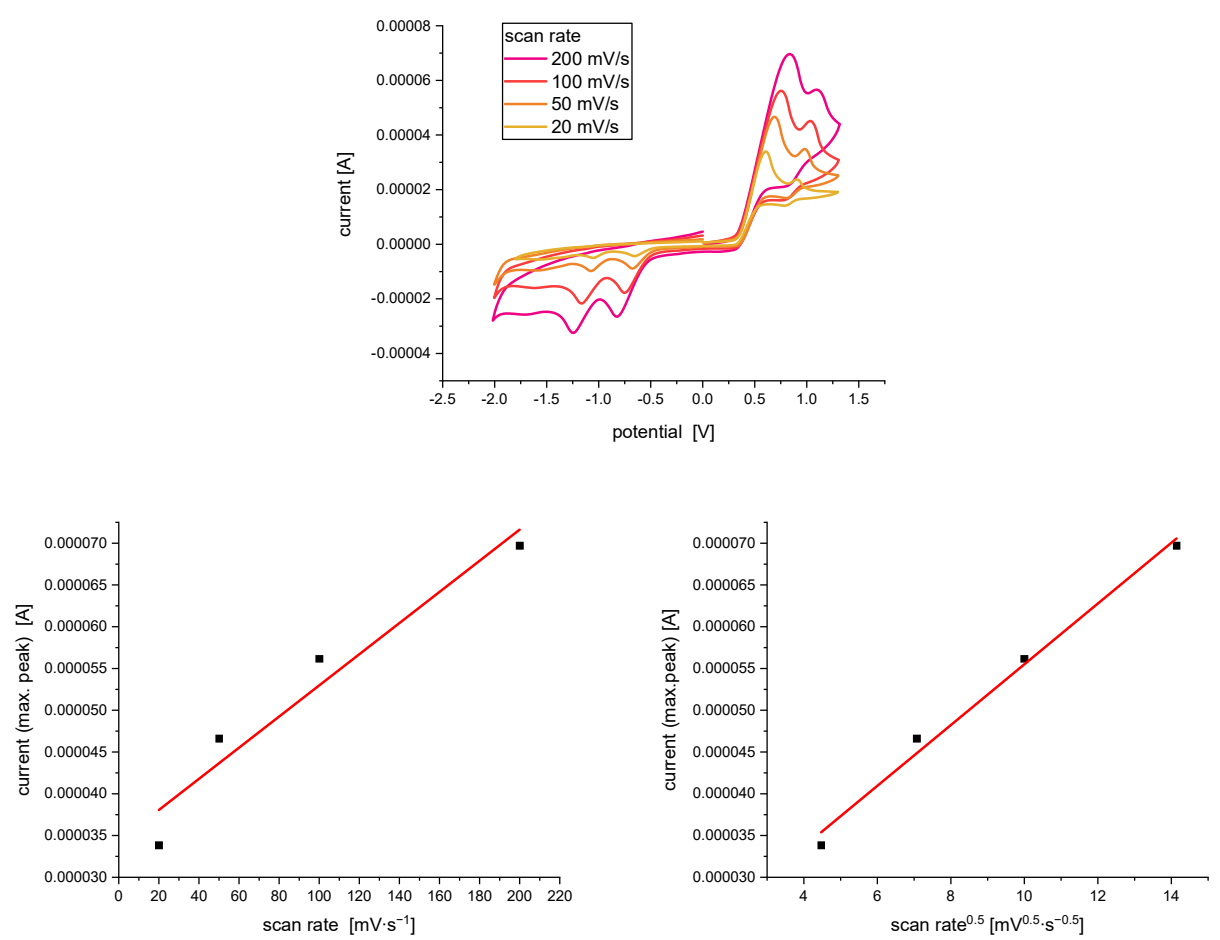

Figure SI-17. Top: Variation of scan rate: OMe-EA with ferrocene as reference (0.05 M in THF) Bottom left: Plot of the maximum current peaks over scan rate (linear fit with $R^{2}=0.91$ ). Bottom right: Plot of the square root of the maximum current peaks over scan rate (linear fit with $R^{2}=0.99$ ). 
